\title{
LA IGUALDAD EN LA DIFERENCIA: LOS DERECHOS COLECTIVOS DE LAS COMUNIDADES ORIGINARIAS
}

\author{
Joaquín PABLO RECA \\ Auxiliar Letrado \\ Suprema Corte de Justicia \\ Provincia de Buenos Aires \\ La Plata (Argentina) \\ joaquinreca_d@botmail.es
}

\begin{abstract}
RESUMEN
El presente trabajo tiene por objeto señalar la especial significación que conlleva el carácter colectivo de los derechos concernientes a las comunidades originarias, sobre los cuales, en definitiva, se cimentan las bases de su supervivencia como grupo. En tal sentido e ilustrativamente, es de observar el caso de Argentina que, tras varios estadios históricos, receptaría esta clase de derechos en su reforma constitucional del año 1994. Naturalmente, este escenario no podia soslayar el Convenio 169 de la OIT de 1989 y la Declaración sobre los Pueblos Indígenas de 2007, cuyas contribuciones han coadyuvado, bajo el halo de la «autonomia» y la «libre determinación», a esta dimensión «colectiva». Por cierto, esta literatura ha sido complementada con aquellos parámetros delineados — desde su faz contenciosa como consultiva - por la Corte Interamericana de Derechos Humanos, órgano que, con motivo de la titularidad que revisten estos pueblos respecto a su propiedad comunal, ha puesto de relieve la interrelación e interdependencia que guardan esta clase de derechos.

Palabras clave: derechos colectivos (diferenciados), el caso de Argentina, desarrollo normativo internacional, propiedad comunal, hitos jurisprudenciales de la Corte IDH.
\end{abstract}

\section{ABSTRACT}

This piece of work aims at pointing at the special meaning implied by the common nature of rights regarding native communities, upon which the foundations for the survival as a group are built. One such case is that of Argentina which, after whipping several stages in history, gathered such rights in the constitutional reform portrayed in 1994. No doubt such panorama could not possibly bypass the ILO 169 Convention of 1989 (Indigenous and Tribal Peoples Convention) or the UN Declaration on the Rights of Indigenous Peoples of 2007, both of which contributions have assisted, under a heaven of «autonomy» and «self determination» this «collective» nature. By the way, such literature has been supplemented with certain criteria outlined (both in its litigation 
as in its advisory stages) by the Inter-American Court of Human Rights. The latter being an institution which, because of the self-determination of such peoples in regard with its co property has outlined the connection and interdependence linking such rights.

Keywords: Collective Rights (discernible), Argentina's Case Scenario, International Normative Development, Communal Property, Milestones in Case Law of the Inter-American Court of Human Rights.

\section{ZUSAMMENFASSUNG}

In diesem Beitrag soll auf die besondere Bedeutung des kollektiven Charakters der Rechte indigener Gemeinschaften hingewiesen werden, auf denen letztlich die Grundlagen für ibr Überleben als Gruppe beruben. In diesem Zusammenhang ist der Fall Argentiniens zu erwäbnen, das nach mebreren bistorischen Etappen diese Art von Rechten in seiner Verfassungsreform von 1994 aufnahm. Natürlich konnten bei diesem Szenario die ILO-Konvention 169 von 1989 und die Erklärung über indigene Völker von 2007 nicht außer Acht gelassen werden, deren Beiträge unter der Begrifflichkeit der «Autonomie» und «Selbstbestimmung» zu dieser «kollektiven» Dimension beigetragen haben. Diese Literatur wurde übrigens durch die vom Interamerikanischen Gerichtshof für Menschenrechte (IACHR) aufgestellten Parameter — sowobl kritisch als auch beratendergänzt, welcher anlässlich des Eigentums dieser Völker an ibrem Gemeinschaftseigentum die Wechselbeziebung und gegenseitige Abhängigkeit dieser Art von Rechten hervorgehoben bat.

Schlüsselwörter: Kollektive Rechte (differenziert), der Fall Argentinien; internationale normative Entwicklung, Gemeineigentum, Meilensteine der Rechtsprechung des IACHR-Gerichtshofs.

SUMARIO: I. INTRODUCCIÓN.-II. HACIA UNA MIRADA COLECTIVA DE LOS DERECHOS DE LOS PUEBLOS INDÍGENAS.-III. BREVE RACCONTO DEL CASO ARGENTINO.-1. La Constitución nacional de 1853.1.1. Desembarco a la reforma constitucional de 1994: algunas consideraciones previas.-1.2. La Constitución de 1994.-IV. LA ÓPTICA INTERNACIONAL EN MATERIA DE PUEBLOS INDÍGENAS.-V. NOTAS DEL SISTEMA INTERAMERICANO DE DERECHOS HUMANOS.-1. Aportes de la Corte Interamericana de Derechos Humanos.-1.1. Algunos hitos jurisprudenciales en materia de propiedad comunal.- 1.2 . Breves menciones de su faz consultiva en torno a los pueblos indígenas.-VI. PALABRAS FINALES.-VII. BIBLIOGRAFÍA.VIII. APÉNDICE JURISPRUDENCIAL. 
«Hay ocasiones en las que somos confrontados, tocados e implicados por las palabras de otro de forma que nos sacan de nosotros mismos y de nuestro punto de vista hacia nuestra humanidad y la humanidad de otros. Esto, me parece, es lo que la voz distintiva de las humanidades puede aportar para ayudarnos a entender lo que significan las violaciones básicas de derechos humanos».

Jonathan LEAR, profesor del Departamento de Filosofía de la Universidad de Chicago ${ }^{1}$.

\section{INTRODUCCIÓN}

En sí, cuando hablamos de los pueblos indígenas ${ }^{2}$, son de vislumbrar sus aspectos diferenciales como grupo, en tanto los mismos se encuentran «enraizados» por sus cimientos identitarios (tradiciones, costumbres, lenguas, artes, rituales, etcétera).

Así, la idea de enfatizar en los derechos colectivos «diferenciados» encuentra su sustento en el hecho de que, a través de los mismos, se logre un abordaje más preciso en lo que hace a sus características únicas, por ejemplo, como acaece con el derecho a sus tierras y territorios, cuyas connotaciones particulares ( $v$. gr., relación espiritual, patrimonio cultural, etc.) no son aprehendidas — más allá de su «intrínseca» relevancia— por los derechos individuales.

Desde ya, estos derechos comunales no pueden soslayar otros derechos que resultan imprescindibles para su ejercicio, como son el de la «autonomía» y la «libre determinación».

Sin embargo, en un mundo globalizado donde predominan intereses individuales, esta clase de derechos muchas veces se suelen tornar en «irruptivos», situación esta que devela ciertas contradicciones por parte de los Estados, los cuales, abogando por los aspectos identitarios de los pue-

${ }^{1}$ Ensayo publicado bajo el título original «The call of Another's Words», en P. BROoKs y H. JewetT (eds.), The Humanities and Public Life, New York, Fordham University Press, 2014, pp. 109-115. Traducción (en prensa) de M. Jimena Sáenz.

2 Con miras a agilizar la lectura, se emplearán los términos «comunidades originarias», «comunidades indígenas», «pueblos originarios» o simplemente «comunidades» o «pueblos». No así el de «poblaciones», debido a que los mismos - reputamos- conciben al «grupo de individuos», negándose su carácter «colectivo-identitario». Por ello, en caso de su mención, la misma responderá a los términos empleados en los instrumentos y organismos internacionales —o regionales - en la materia. Sin embargo, vale aclarar que cada una de las comunidades conllevan aspectos diferenciales entre sí. 
blos indígenas, se adhieren — con una tendencia a ser priorizados— a regímenes internacionales de comercio.

Frente a tal panorama, estamos convencidos que estos atributos inherentemente diferenciales resultan una piedra fundamental que, en definitiva, esculpe y define la identidad de los pueblos indígenas. Dicho de otra forma, entendemos que no sería asequible el estudio o análisis de las problemáticas que los asisten si se prescinde de su horizonte colectivo.

Por ello, la edificación en el bienestar, dignidad y supervivencia (de generaciones presentes y futuras) de estos agentes postergados implica una aproximación de alteridad que contribuya a la constitución de un escenario (polifónico) donde se reconozca el derecho de estos pueblos «a ser diferentes, a considerarse a sí mismos diferentes y a ser respetados como tales» ${ }^{3}$.

\section{HACIA UNA MIRADA COLECTIVA DE LOS DERECHOS DE LOS PUEBLOS INDÍGENAS}

Como se dijo, a la hora de realizar cualquier ponderación en relación con los pueblos indígenas resulta cardinal reparar en sus derechos colectivos, es decir, tomar en consideración sus aspectos diferenciales como «grupo», con el objeto de compensar «las circunstancias desiguales» que los hicieron estar «sistemáticamente en desventaja en el mercado cultural» ${ }^{4}$. Ello, claro está, no debe traducirse en un aislamiento respecto de la cultura mayoritaria, necesaria para su desenvolvimiento ( $v$. gr., necesitar competencias de autogobierno o representación parlamentaria para los

\footnotetext{
3 Apartado 2 del Preámbulo de la Declaración de las Naciones Unidas sobre los derechos de los Pueblos Indígenas, disponible en https://www.un.org/esa/socdev/unpfii/ documents/DRIPS_es.pdf.

${ }^{4}$ W. Kymlicka, Ciudadanía multicultural: una teoría liberal de los derechos de las minorías, Barcelona, Paidós Ibérica, 1996, p. 27, disponible en https://www.academia. edu/31489607/Ciudadan\%C3\%ADa_multicultural_Una_teor $\%$ C3\%ADa_liberal_de_los_ derechos_de_las_minor $\%$ C3\%ADas_Will_Kymlicka_Editorial_Paid $\%$ C $3 \%$ B Bs__T\% $\% 3 \%$ ADtulo_original_Multicultural_citizenship_A_liberal_theory_of_minority_rights (consultado el 1 de diciembre de 2020). En esa misma sintonía, Cliffor Geertz considera que el orden cultural de los pueblos indígenas produce vínculos significativos que «atenúan las contingencias de la vida individual». Vid., en tal sentido, C. DEL CaIro y J. JaramiLLO MARín: «Clifford Geertz y el ensamble de un proyecto antropológico crítico», Tabula Rasa: Revista de Humanidades, núm. 8 (2008), p. 24, disponible en bttps://revistas.unicolmayor.edu.co/index.php/tabularasa/article/view/1509/2042 (consultado el 24 de noviembre de 2020).
} 
movimientos indígenas) ${ }^{5}$, pese a que se corra el riesgo de que las comunidades se alejen de su identidad y dinámicas organizativas particulares que los constituyen ${ }^{6}$.

Sin embargo, esta clase de derechos $-\mathrm{y}$ su heterogeneidad $-{ }^{7}$ revelan, con asiduidad, tensiones con los Estados democráticos ${ }^{8}$. Y es que, como señala el constitucionalista norteamericano Robert Charles Post, si bien la Constitución de un Estado debe abogar por la diversidad cultural (v. gr., lingüística, religiosa, etc.), esta correspondencia jurídico-social es generadora de (más) tensiones ${ }^{9}$, en cuanto «el Estado fomenta inevitablemente determinadas identidades culturales y, por consiguiente, perjudica a otras» ${ }^{10}$.

Es en este contexto — donde la legitimidad de «intereses de grupo» se «encuentra potencialmente en tensión dinámica o analítica con los prerrequisitos de la unidad constitucional»- ${ }^{11}$ en el que estimamos conveniente el mecanismo de «devolución (o traspaso) de soberanía», entendida esta como «una cesión por parte de la cultura nacional a un grupo de la autoridad para establecer el derecho» ${ }^{12}$, siendo tal cauce el más óptimo para la defensa de los pueblos indígenas, en tanto atiende «a valores que pueden ser percibidos por la cultura nacional como parciales y anómalos» ${ }^{13}$, pero que, para la cultura subordinada (léase indígena), devienen universales ${ }^{14}$.

Por el contrario, los derechos individuales $(v, g r$, «libertad de expresión», «libertad de culto» o «libertad religiosa», etc.), más allá de significar

5 W. Kymlicka, Ciudadanía multicultural: una teoría liberal..., op. cit., p. 41.

${ }^{6}$ D. ITURRALDE, «Demandas indígenas y reforma legal: retos y paradojas», Alteridades, núm. 14 (1997), p. 86, disponible en https://alteridades.izt.uam.mx/index.php/Alte/article/ view/514/512 (consultado el 2 de diciembre de 2020).

${ }^{7}$ La misma no es inherente a todo grupo ( $v . g r$., corporaciones).

${ }^{8}$ En ocasiones, este panorama reivindicatorio de derechos colectivos suele ser interpretado - ya sea por autoridades públicas o grupos privados - como un resquebrajamiento de la «seguridad nacional» (de su unidad y los recursos estratégicos de un país). Vid. D. ITURRALDE, «Demandas indígenas y reforma legal...», op. cit., p. 93.

9 R. Post, «Constitucionalismo democrático y heterogeneidad cultural», Revista Jurídica, núm. 1 (2008), pp. 5-7 (el artículo fue publicado originalmente en el año 2000 en Australian Journal of Legal Philosophy, vol. 25, núm. 2), disponible en https://www.palermo.edu/ derecho/revista_juridica/09Jurica01.pdf (consultado el 1 de diciembre de 2020).

${ }^{10}$ Entre los supuestos que invoca Kymlicka, tal como acontece en países como Canadá, Bélgica o España, se encuentran los concernientes a los «derechos lingüísticos». Vid. W. Kymlicka, Ciudadanía multicultural: una teoría liberal..., op. cit., pp. 27-31.

${ }_{11}$ R. Post, «Constitucionalismo democrático y heterogeneidad...», op. cit., p. 19.

12 Con sus limitaciones ( $v, g r$., no legislar sobre ciertas materias).

13 R. Post, «Constitucionalismo democrático y heterogeneidad...», op. cit., p. 22.

${ }^{14}$ Ibid., p. 23. 
una contribución a los distintos enfoques culturales que se presentan en la sociedad, no resultan ser una herramienta eficaz a los fines de resguardar la identidad ${ }^{15}$ - colectiva — de las comunidades originarias, puesto que reflejan valores socialmente predominantes, protegiendo muchas veces aquella diversidad «funcional» al sistema preponderante ${ }^{16}$.

\section{BREVE RACCONTO DEL CASO ARGENTINO}

\section{La Constitución nacional de $\mathbf{1 8 5 3}$}

Ahora bien, en vista de la naturaleza «colectiva» de los derechos de estos pueblos, cabe reparar en la recepción que de los mismos ha tenido Argentina.

Así, debemos remontarnos a la Constitución nacional de 1853, cuyo articulado nos permite observar que la cuestión indígena fue atendida en una sola de sus cláusulas normativas, tal como se plasmó en el art. 67 («De las atribuciones del Congreso») ${ }^{17}$, que en su inciso $15^{18}$ rezaba: «Proveer a la seguridad de las fronteras, conservar el trato pacífico con los indios y promover la conversión de ellos al catolicismo» ${ }^{19}$.

Se sigue de ello, y de una lectura literal del texto normativo, una clara distinción peyorativa — propia de la época— ${ }^{20}$ entre la «civilización»

${ }^{15}$ La misma puede ser concebida como la «conciencia de la diferencia y de la situación de desventaja que ha implicado históricamente, y voluntad de superarla precisamente mediante el reforzamiento de las prácticas que los hacen distintos como la lengua, las formas de organización, las tradiciones». Vid. D. ITURRALDE «Demandas indígenas y reforma legal...», op. cit., p. 85 .

${ }_{16}$ R. Post, «Constitucionalismo democrático y heterogeneidad...», op. cit., p. 12.

17 Dicha previsión normativa debe ser leída paralelamente con los arts. 2 («El Gobierno federal sostiene el culto católico apostólico romano») y 25 («El Gobierno federal fomentará la inmigración europea») de aquella Carta Magna que, hasta la actualidad, siguen vigentes.

${ }_{18}$ El mismo se encontraba en sintonía con otra de las «atribuciones del Congreso», como lo era la determinación de «los límites de la Nación, fijar los de las provincias, crear otras nuevas y determinar por una legislación especial la organización, administración y gobierno que deben tener los territorios nacionales» (art. 67.14 de la Const. nac.).

19 Disponible en http://www.biblioteca.jus.gov.ar/constitucionargentina1853. btml (consultado el 9 de diciembre de 2020).

${ }^{20}$ En esta sintonía cabe señalar lo sucedió en otras cartas magnas en aquel entonces. Así, la Constitución de 1830 de Ecuador establecía, entre las facultades del Congreso, el nombramiento de curas párrocos para ser «tutores y padres naturales de los indios» (art. 68). En análogo sentido, en la Constitución Federal de Centroamérica de 1835 se procuraba «la civilización de las tribus indígenas». Vid. B. CLAVERO, «Pronunciamientos indíge- 
(nosotros) y la «barbarie» (ellos), donde los «indios» ${ }^{21}$ eran ubicados en esta última categoría, quienes, al formar parte del territorio (de nosotros), debían someterse a la religión imperante. En otras palabras, si su voluntad era habitar el territorio argentino, debían despojarse de sus singularidades colectivas (identidad cultural, tradición, costumbres, creencias), en tanto lo indígena no era parte de la nación ${ }^{22}$.

\subsection{Desembarco a la reforma constitucional de 1994: algunas consideraciones previas}

Habida cuenta de dicha referencia normativa, y a los fines de una mejor comprensión de su texto reformado en el año 1994, caben señalar algunos acontecimientos históricos atinentes a las comunidades indígenas.

En ese sentido, los antropólogos argentinos Gastón Gordillo y Silvia Hirsch destacan la presencia de las fuerzas militares durante el siglo XIX, tal como se reflejó con la denominada «campaña del desierto» de 1879 diri-

nas de las Constituciones americanas», 2013, disponible en http://www.alertanet.org/constitucion-indigenas.htm (consultado el 9 de diciembre de 2020).

${ }^{21}$ En este aspecto e ilustrativamente resulta interesante recordar la obra de teatro (representada por primera vez en 1611) de William SHAKESPEARE, La Tempestad, cuya alegoría - para los periodos coloniales - nos permite observar, en distintos de sus pasajes y por medio de sus dos protagonistas principales, Próspero (el duque de Milán de derecho) y Calibán (esclavo salvaje y deforme), la mirada del «nosotros» respecto a «ellos». Así, en la Escena II del Acto I («La Isla. Delante de la celda de Próspero») —en donde estos dos personajes se ponen a dialogar - se desprenden versos como: «iCalibán! ¡Criatura de la tierra, Tú! Habla (Próspero)». Sin embargo, entendemos que uno de los versos más significativos es el que pronuncia Calibán: «Esta isla es mía. La heredé de Sýcorax, mi madre, y tú me la quitaste. Al principio, cuando llegaste aquí, me acariciabas, y me tenías en mucho; solías darme agua de bayas, y me enseñaste a nombrar la Luz más grande, y la menor, que arden de día y de noche. Yo entonces te amaba, y te mostré todas las cualidades de la Isla, los manantiales de agua clara, las minas de salmuera, lugares fértiles y yermos: ¡En mala hora lo hice! ¡Que todos los hechizos de Sýcorax, sapos, escarabajos y murciélagos, lluevan sobre vosotros, Pues yo soy todos los sujetos que tenéis, yo, que era antes mi propio Rey!». Vid. W. Shakespeare, La Tempestad, traducida al castellano por M. Palazón Blasco, Madrid, Bubok, 2011, pp. 23-25.

22 En tal sentido, los/as autores/as Virginia García Acosta, Luís Roberto Cardoso de Oliveria, Alcida Rita Ramos y Mercedes Oliva, en el marco comparativo — de inclusión indígena- entre Brasil y Argentina, recuerdan el chiste: «al contrario de los peruanos que vinieron de los incas y de los mexicanos que vinieron de los aztecas, los argentinos dicen que vinieron de los barcos», lo que, más allá de parecer irrelevante, contextualiza una idiosincrasia imperante que se mantiene en la actualidad. Acúdase, interés mediante, a su artículo «Diálogos México-Brasil», Desacatos, núm. 39 (2012), p. 168, disponible en http://www.scielo.org.mx/pdf/desacatos/n39/n39a11.pdf (consultado el 10 de diciembre de 2020). 
gida por el general Julio Argentino Roca donde, junto con otras campañas de idénticas características en los años 1881 y 1885, se conquistaron —por medio del abatimiento de la resistencia de ciertos pueblos indígenas «en la llanura pampeana, el río Negro y el Neuquén»— ${ }^{23}$ grandes extensiones de territorio.

Este contexto puede ser interpretado como uno de «etnocidio», es decir, de «destrucción sistemática de los modos de vida y de pensamiento», donde a los «otros» («los diferentes») puede «mejorárselos, obligándolos a transformarse hasta que, si es posible, sean idénticos al modelo que se les propone» (al igual que en el genocidio) ${ }^{24}$. Sin embargo, Gordillo y Hirsch advierten — sin minimizar las vidas que se perdieron en el camino y la desestructuración social que se generó- que sería contradictorio inferir tal panorama como uno de exterminio en tanto «la presencia de los grupos recientemente derrotados guiaba políticas de gobierno y la expansión de fronteras capitalistas» ${ }^{25}$, en el cual grupos indígenas formarían parte de nuevas composiciones sociales, tales como trabajos estacionales o como fuerza de producción agrícola $(v$. gr., algodoneros, azucareros, entre otras actividades).

Más allá de esto, y frente a ciertos esfuerzos durante el siglo $\mathrm{xx}^{26}$ para que se visibilizara la cuestión indígena — con la conformación de la primera institución nacional que tratara los asuntos indígenas como fue la Comisión Honoraria de Reducciones de Indios ${ }^{27}$ (creada en 1916 y disuelta en 1946) —, los temas que involucraban la órbita de las comunidades originarias seguían el rumbo de lo incorpóreo ${ }^{28}$.

${ }^{23}$ G. Gordillo y S. Hirsch, «Movilizaciones indígenas e identidad en disputa en la Argentina», Programa en Antropología Social y Política de FLACSO, Buenos Aires, La Crujía, 2010, p. 20, disponible en https://www.academia.edu/19869642/La_presencia_ausente_ invisibilizaciones_pol\%C3\%ADticas_estatales_y_emergencias_ind\%C3\%ADgenas_en_la_ Argentina (consultado el 10 de diciembre de 2020).

${ }_{24}$ P. Clastres, «Sobre el etnocidio», en Investigaciones en Antropología Política, Barcelona, Gedisa, 1996, pp. 56-57, disponible en bttps://iidypca.homestead.com/FundamentosAntropologia/Clastres_-_Sobre_el_etnocidio.pdf (consultado el 10 de diciembre de 2020).

${ }^{25}$ G. Gordillo y S. Hirsch, «Movilizaciones indígenas e identidad en disputa...», op. cit., p. 21.

${ }^{26}$ El periodo comprendido entre los años 1900 a 1930 se caracterizó principalmente por la conflictividad que aparejaban las condiciones laborales de las que resultaban destinatarios los pueblos indígenas $(v \cdot g r$, explotación, restricciones sobre la movilidad) y que, consecuentemente, por parte de autoridades estatales derivaron en masacres que incluyeron «niños». Vid. ibid., p. 23.

${ }_{27}$ Su constitución primigenia tenía como finalidad «las reducciones indígenas de Napalpí (Chaco) y Bartolomé de las Casas (Formosa). Vid. ibid., p. 22.

${ }^{28}$ Ibid., nota 27. 
Posteriormente, con el advenimiento del gobierno de Juan Domingo Perón (1946) —y su «retórica populista e inclusiva»— se comenzaría a avizorar un cambio de rumbo en la edificación de las «políticas indigenistas», cuyo direccionamiento, pese a ciertos comportamientos gubernamentales $^{29}$, se sustentó en la ampliación de derechos sociales y políticos de las comunidades indígenas ( $v$. gr., voto, mejoras laborales), contribuyendo, de esa forma, a la presencia de dirigentes indígenas en la esfera de la burocracia estatal ${ }^{30}$.

Ya para el año 1955, con la sublevación cívico-militar y el derrocamiento del segundo mandato de Perón, se produjeron ciertos retrocesos en lo referente a los asuntos indígenas, como se observó con la disolución de la hasta entonces Dirección de Protección Aborigen —antigua Comisión Honoraria de Reducciones de Indios- A pesar de ello, también se atisbaron algunos avances derivados de la elaboración de «censos» indígenas, lo cual - empero ciertas estigmatizaciones en sus resultados - se tradujo en una mayor visibilidad ${ }^{31}$ cuantitativa indígena ${ }^{32}$.

Más tarde, los años 1966 a 1983 contarían con la presencia de distintos movimientos (políticos, guerrilleros, etc.) que, enarbolando la «causa indígena», coadyuvaron a la creación de diversos espacios (Comisión Coordinadora de Instituciones Indígenas, así como también, y entre otras, la Confederación Indígena Neuquina) donde se debatían —en cada una de ellas de diferente manera- asuntos ceñidos a temas del tipo étnico-cultural o reivindicaciones del tipo político-económicas ${ }^{33}$. Estos precedentes, no obstante la disipación que sufrirían dichas organizaciones por intervenciones estatales, se constituyeron en una base imprescindible para que dirigentes situados en urbes fundaran en 1975 la Asociación Indígena de la República Argentina (AIRA), «centrada en demandas de corte cultural y étnico» ${ }^{34}$.

${ }^{29}$ Tal el caso del «malón de la paz» — cuya importancia radica en haber sido el primer antecedente de movimientos indígenas en Argentina-, debido a que, ante las protestas de campesinos Kollas — quienes, simbólica y políticamente, «marcharon a pie hasta Buenos Aires en demandas de títulos de tierra»-, sus miembros fueron recibidos y, posteriormente, encerrados en trenes para que volvieran a sus Provincias (de Salta y Jujuy). Vid. ibid., p. 24.

${ }^{30}$ Ibid., nota 29.

31 A estos fines se recomienda acceder al siguiente enlace en donde se podrá visualizar, en el apartado «Mapa de comunidades indígenas», todos aquellos pueblos que habitan actualmente en el territorio de la Provincia de Buenos Aires, disponible en https://www.gba.gob.ar/ derechoshumanos (consultado el 10 de diciembre de 2020).

32 G. Gordillo y S. HirSCH, «Movilizaciones indígenas e identidad en disputa...», op. cit., pp. 25-26.

${ }^{33}$ Ibid., pp. 26-27.

${ }^{34}$ Dentro de sus objetivos, conforme se puede deducir de su página oficial, se encuen- 
Sin embargo, con el derrocamiento de las autoridades constitucionales de entonces y el posterior arribo del gobierno militar en turno el 24 de marzo de 1976 se buscaría — con manifestaciones celebratorias de aquellas heridas aún abiertas (campaña del desierto) — restablecer la concepción de «la barbarie indígena».

Finalmente, interesa señalar —en razón de las distintas articulaciones que años anteriores ya atestiguaban las deslegitimaciones de las que devenían titulares las comunidades originarias- que a partir de $1980^{35}$ comenzaría un periodo donde los cimientos de la materia indígena eran cada vez más sólidos, plasmándose en distintas disposiciones normativas como, por ejemplo, la del art. 1 de la Ley 23.302 «sobre política indígena y apoyo a las comunidades aborígenes» ${ }^{36}$, que declaraba «de interés nacional la atención y apoyo a los aborígenes y a las comunidades indígenas existentes en el país», con el objetivo - a tal efecto- de implementar políticas públicas que permitieran, respetando sus identidades culturales, el «acceso a la propiedad de la tierra» ${ }^{37}$. De ese modo, guardando correspondencia con sus objetivos, también la norma contemplaba la creación del «Instituto Nacional de Asuntos Indígenas», entidad esta que, con la «participación indígena», funcionaba como órgano supervisor de la norma ${ }^{38}$.

tran la «defensa y desarrollo de las comunidades indígena en todos sus aspectos: económicos, sociales, sanitarios, idiomáticos y jurídicos», disponible en bttps://www.aira.org.ar/ (consultado el 11 de diciembre de 2020).

${ }^{35}$ Cabe destacar, en línea con la especialista peruana Raquel Yrigoyen Fajardo, que dicho periodo (1982-1988) se enmarcó dentro del primer ciclo de reformas constitucionales —que se venían produciendo en países como Canadá (1982), Guatemala (1985) y Nicaragua (1987), entre otros— que se denominó «constitucionalismo multicultural». Dicho de otra manera, las constituciones «introducen el concepto de diversidad cultural, el reconocimiento de la configuración multicultural y multilingüe de la sociedad, el derecho -individual y colectivo- a la identidad cultural y algunos derechos indígenas específicos». Puede consultarse en R. YRIGOYEN FAJARDO, «El horizonte del constitucionalismo pluralista: del multiculturalismo a la descolonización», en C. Rodríguez Garavito (coord.), El Derecho en América Latina. Un mapa para el pensamiento jurídico del siglo XXI, Buenos Aires, Siglo XXI, 2011, capítulo 6, p. 141, disponible en bttp://www.justiciaglobal.net/files/actividades/fi_name_ recurso.8.pdf\#page $=138$ (consultado el 26 de noviembre de 2020).

${ }^{36}$ La misma fue sancionada el 30 de septiembre de 1985 e implementada en 1989.

37 En referencia con aquello cabe destacar el apartado IV ( $«$ De la adjudicación de tierras»), cuyos enunciados normativos, que disponían el otorgamiento «de tierras aptas y suficientes» para las diversas actividades de las comunidades, reflejaba la heterogeneidad de las mismas (v. gr., «según las modalidades propias de cada comunidad», cfr. art. 7).

38 Disponible en bttp://servicios.infoleg.gob.ar/infolegInternet/anexos/20000-24999/ 23790/texact.htm (consultado el 12 de diciembre de 2020). Léase, de manera conjunta y en caso de interés, el Decreto-ley 701/2010, de 20 de mayo de 2010, disponible en http:// servicios.infoleg.gob.ar/infolegInternet/verNorma.do? $i d=167618$ (consultado el 12 de diciembre de 2020). 


\subsection{La Constitución de 1994}

Después del paisaje histórico someramente comentado, y al calor de demandas provenientes de «dirigentes y militantes indígenas y miembros de ONGs» ${ }^{39}$, se llevó a cabo la reforma constitucional del año $1994^{40}$.

Dicho acontecimiento normativo - que se presenta en el marco del «constitucionalismo pluricultural»- ${ }^{41}$ nos conduce a reparar en el art. 75, inciso 17 («De las atribuciones del Congreso») ${ }^{42}$, el cual reza: «Reconocer la preexistencia étnica y cultural de los pueblos indígenas argentinos. Garantizar el respeto a su identidad ${ }^{43}$ y el derecho a la educación bilingüe e intercultural; reconocer la personería jurídica de sus comunidades, y la posesión y propiedad comunitarias de las tierras que tradicionalmente ${ }^{44}$ ocupan; y regular la entrega de otras aptas y suficientes para el desarrollo humano; ninguna de ellas será enajenable, transmisible ni susceptible de gravámenes o embargos. Asegurar su participación en la gestión referida a sus recursos naturales y a los demás intereses que los afecten. Las provincias pueden ejercer concurrentemente estas atribuciones» ${ }^{45}$.

39 G. Gordillo y S. Hirsch, «Movilizaciones indígenas e identidad en disputa...», op. cit., p. 29.

${ }_{40}$ Por su parte cabe señalar que, a diferencia de los casos de Colombia y Venezuela, su elaboración no contó con convencionales constituyentes indígenas.

${ }^{41}$ Este ciclo de reformas (1989-2005), que complementa el «constitucionalismo multicultural» desarrollando conceptos de «nación multiétnica/multicultural» y de «Estado pluricultural», se singularizó en cuanto las constituciones introdujeron —como principios básicos- «las fórmulas de pluralismo jurídico» que permitían emigrar de la concepción jurídica monista, esto es, de la idea de que «solo es "Derecho" el sistema de normas producido por los órganos soberanos del Estado» (los poderes Legislativo, Judicial y Ejecutivo). Vid. R. FAJARDO, «El horizonte del constitucionalismo pluralista...», op. cit., p. 142.

${ }^{42}$ En idéntico sentido que la Carta Magna de 1853 (art. 67.15), se dispone que el Congreso estará a cargo de «proveer la seguridad de las fronteras» (art. 75.16).

${ }^{43}$ Colegimos que la misma es el punto central por y desde el cual debe ser analizada la disposición normativa aquí comentada.

${ }^{44}$ Cabe destacar que la también reformada Constitución de la Provincia de Buenos Aires de 1994 reivindica, a los fines de eliminar todos aquellos obstáculos que vulneren o impidan el efectivo goce de los derechos y garantías constitucionales, la existencia de los pueblos indígenas, garantizando — entre sus aspectos medulares- el respeto no ya de las tierras que «tradicionalmente ocupan», sino de las que «legítimamente ocupan» (cfr. art. 36.9), lo cual trasunta — consideramos- más allá de una mera cuestión semántica Vid. http://www.infoleg.gob.ar/?page_id=173 (consultado el 12 de diciembre de 2020).

45 Empero de lo auspicioso que esta previsión constitucional resulta, también es de destacar que en el mismo no se contempla, difiriendo - entre otros casos- de la Constitución Política del Perú de 1993 (art. 149) y de la Constitución Política de Colombia de 1991 (Título VIII, «De la rama judicial», art. 246), la «jurisdicción indígena». Ello repercute de mane- 
Se deduce de la previsión constitucional un matiz «instrumental» indígena $\left(v . g r\right.$., «personería jurídica» que ostentan y su «participación» ${ }^{46}$ en los intereses que los afecten) y otro «sustantivo» (v. gr., «educación» y el «status de las tierras»).

Este panorama ${ }^{47}$, claro está, no puede prescindir de la incorporación de tratados internacionales —en especial aquellos que se circunscriben a los derechos humanos-, que fueron incorporados con dicha reforma en el art. 75, inciso 22. En ese orden cabe destacar que el núcleo normativo en materia indígena se encuentra ceñido, principalmente y como mencionaremos seguidamente, por el Convenio 169 de la Organización Internacional del Trabajo ${ }^{48}$ (en adelante, OIT) sobre «Pueblos Indígenas y Tribales en Países Independientes», por la Declaración de las Naciones Unidas sobre «Los derechos de los Pueblos Indígenas» (en adelante, UNDRIP) y, en lo que hace al sistema regional de derechos humanos, la Declaración Americana sobre «Los derechos de los Pueblos Indígenas» (en adelante DADPI).

Asimismo, en esta sintonía constitucional, interesa señalar el cambio de postura que adoptara - luego de 1994- la Corte Suprema de Justicia de la Nación (en adelante, CSJN) en aquellos asuntos que tuvieran

ra negativa en lo que hace a la proyección de la «autonomía indígena», la cual se detallará en las siguientes líneas del presente trabajo.

${ }^{46}$ Aquí se sitúa el derecho a la «consulta».

${ }^{47}$ Se recomienda la lectura del mismo tomando en consideración otras disposiciones normativas, tales como, por ejemplo, la Ley 26.160 de 2006 (declara la emergencia en posesión y propiedad de las tierras que tradicionalmente ocupan las comunidades indígenas); la Ley 26.331 y su Decreto reglamentario 91/2009 (presupuestos mínimos de protección ambiental de bosques nativos), y los arts. 18 (derecho a la posesión y propiedad comunitaria de las tierras que tradicionalmente ocupan) y 63.c) (derecho de los pueblos indígenas a inscribir nombres en idiomas originarios) de la Ley 26.994 de 8 de octubre del 2014 (aprobatoria del Código Civil y Comercial de la Nación), disponible en bttps://www.argentina.gob.ar/ derechoshumanos/inai/normativa (consultado el 12 de diciembre de 2020).

${ }^{48}$ Colegimos de importancia capital recordar que, pese a su injerencia en la materia bajo estudio (derechos humanos de índole colectivo diferencial), dicho instrumento (ratificado por Argentina el 3 de julio del 2000) no posee — de conformidad con el primer párrafo del art. 75, inciso 22, de la Constitución nacional que establece, entre las atribuciones del Congreso, la de aprobar y desechar tratados concluidos con las demás naciones y con las «organizaciones internacionales»- jerarquía constitucional, sino que su estamento normativo es «superior a las leyes» (art. 75.22, primer párr.). De ahí que, en base a la trascendencia del presente tratado, la Cámara de Diputados de la Nación presentó el 7 de marzo de 2018 un proyecto (expediente 0475-D-2018) donde se solicita elevar el instrumento a la cúspide jurídica del ordenamiento legal, en tanto ello representaría reconocer «constitucionalmente el derecho consuetudinario de las comunidades indígenas». Vid. https:// www.hcdn.gob.ar/proyectos/proyecto.jsp?exp=0475-D-2018 (consultado el 21 de diciembre de 2020). 
como actores principales a los pueblos indígenas. En efecto, ello se puede observar con la convocación, por medio de audiencias públicas, a distintos miembros de comunidades originarias.

En esa dirección es menester recordar algunos precedentes como el caso Defensor del Pueblo de la Nación c. Estado nacional y otra (Provincia de (baco) ${ }^{49}$ s/ proceso de conocimiento, del 18 de septiembre de 2007, en cuya oportunidad la CSJN, haciendo lugar a la medida cautelar (suministro de agua potable, alimentos, medios de transporte y comunicación adecuados a cada uno de los puestos sanitarios) solicitada por los habitantes de la región sudeste del Departamento de Güemes y noroeste del Departamento Libertador General San Martín de la Provincia de Chaco - «en su gran mayoría pertenecientes a la etnia Toba»-, convocó una audiencia pública a celebrarse en sus estrados ${ }^{50}$ (vid. apdo. II). De igual manera aconteció el 22 de mayo de 2012 en el caso Comunidad Indígena Toba La Primavera-Navogoh c. Formosa, Provincia de y otros s/medida cautelar, donde la CSJN convocaría una segunda audiencia pública con la presencia de los presidentes de la Comunidad Qom Potae Napocna Navogob (La Primavera), de la Asociación Civil Comunidad Aborigen La Primavera y del Instituto Nacional de Asuntos Indígenas ${ }^{51}$.

Sin embargo, y como advierte el constitucionalista argentino Miguel Ángel Benedetti y la doctora argentina María Jimena Sáenz, dichos precedentes no cuentan aún con una sentencia de la CSJN, lo cual podría sugerir «que las audiencias públicas podrían agotarse en un mero efecto simbólico, como si su puesta en escena judicial solo hubiera funcionado para visibilizar esos acuciantes problemas que estaban ocultos en el foro público» ${ }^{52}$.

49 Es menester señalar que, recientemente (diciembre de 2020), en dicha Provincia se aprobó la modificación del Código Procesal Civil y Comercial provincial, por la cual se dispuso, en aquellos procesos donde estén en juego derechos de incidencia colectiva, la gratuidad con la que cuentan para litigar los pueblos indígenas y sus organismos representativos. Vid. https://www.chacodiapordia.com/2020/12/11/comunidades-indigenasdel-chaco-podran-litigar-gratis-en-defensa-de-sus-derechos/ (consultado el 11 de diciembre de 2020).

${ }_{50}$ Disponible en bttp://www.derechoshumanos.unlp.edu.ar/assets/files/documentos/ defensor-del-pueblo-de-la-nacion-c-estado-nacional-y-otro-derecho-a-la-vida-digna-comunidadesin-pdf (consultado el 12 de diciembre de 2020).

${ }_{51}$ Disponible en http://sjconsulta.csjn.gov.ar/sjconsulta/documentos/verUnicoDocumentoLink. html? idAnalisis=15696Ecache $=1607821187901$ (consultado el 12 de diciembre de 2020).

52 M. BenEDETTI y M. SÁENZ, «Decisión judicial y participación ciudadana: los impactos de las audiencias públicas en las sentencias de la Corte Suprema argentina», Eunemia, núm. 15 (2018-2019), p. 113, disponible en https://e-revistas.uc3m.es/index.php/EUNOM/ article/view/4343/2887 (consultado el 12 de diciembre de 2020). 


\section{LA ÓPTICA INTERNACIONAL EN MATERIA DE PUEBLOS INDÍGENAS}

Habiendo dicho esto, y en tanto se generen episodios de vital importancia a la hora de diseñar el horizonte indígena, cabe abocarnos al Convenio 169 de la OIT del 27 de junio de $1989^{53}$ y a la UNDRIP del 13 de septiembre de $2007^{54}$, instrumentos estos que, teniendo como únicos des-

53 El mismo entraría en vigor el 5 de septiembre de 1991.

${ }^{54}$ Ello no empece —no obstante la carencia de «cláusulas indígenas»— para desconocer aportes provenientes de otros instrumentos y órganos internacionales y regionales, a saber: la Convención para la Prevención y la Sanción del Delito de Genocidio, que en su art. 2 prevé un concepto de «genocidio»; la Carta Interamericana de Garantías Sociales —en tanto ni la Declaración Americana de los Derechos y Deberes del Hombre de 1948 ni la Convención Americana sobre Derechos Humanos de 1969 contienen referencias al respecto-, que en su art. 39 impone a los Estados deberes de adoptar distintas medidas para prestar protección al «indio» («amparándole la vida, la libertad, la propiedad y defendiéndolo del exterminio», debiéndose crear instituciones a tal efecto y a los fines de respetar sus tierras, legalizar su posesión por los mismos y evitar la invasión de tales tierras); la Convención relativa a la lucha contra la discriminación en la esfera de la enseñanza (UNESCO, 1960); la Convención Internacional sobre la Eliminación de Todas las Formas de Discriminación Racial de 1965, cuyo art. 1 contempla la denotación de la discriminación racial; el Protocolo Adicional a la Convención Americana sobre Derechos Humanos en materia de Derechos Económicos, Sociales y Culturales o «Protocolo de San Salvador», que más allá de no mencionar expresamente a las comunidades originarias, resulta relevante en cuanto a sus disposiciones en materia de salud, medio ambiente y participación en la vida cultural; el Pacto Internacional de Derechos Económicos, Sociales y Culturales de 1966, que, al igual que el Pacto de Derechos Civiles y Políticos (1966), establece en su art. 1 el derecho de todos los pueblos a «la libre determinación»; el Pacto de Derechos Civiles y Políticos, cuyo art. 27 establece el respeto a los derechos de las «minorías» de un Estado a tener «su propia vida cultural, a profesar y a practicar su propia religión, y a emplear su propio idioma», siendo esta previsión normativa complementada con diversas Observaciones Generales (en adelante, OG) del órgano supervisor del tratado, como lo es el Comité de Derechos Humanos, en cuya oportunidad tuvo dicho - entre otros aspectos - que el disfrute de una determinada cultura — como la de los pueblos indígenas- puede guardar relación con modos de vida estrechamente asociados al territorio y al uso de recursos (OG 23, 1994); la Declaración sobre la Raza y los Prejuicios Raciales (UNESCO, 1978); el Informe final del «Estudio del problema de la discriminación contra la poblaciones indígenas» (1987), confeccionado por el relator de la Subcomisión de Prevención de Discriminaciones y Protección a las Minorías, el ecuatoriano José Martínez Cobo, donde, entre otros puntos, incluía una definición de las poblaciones indígenas, la connotación particular de las tierras para los pueblos indígenas (apdos. 196, 197 y 198), el papel de las organizaciones intergubernamentales y de las organizaciones no gubernamentales, los principios básicos y la eliminación de la discriminación en materia de derechos humanos, ya advirtiendo que, bajo la situación en la que se encuentran las poblaciones, se propiciaba a que las mismas fueran objeto de discriminación, opresión y explotación [disponible en bttp://cendoc. docip.org/collect/cendocdo/index/assoc/HASH0151/8c042321.dir/EstudioCobo_conclus_es1. $p d f$ (consultado el 4 de diciembre de 2020)]; la Declaración sobre los Derechos de las Personas Pertenecientes a las Minorías Nacionales o Étnicas, Religiosas o Lingüística de 1992; la 
tinatarios a las comunidades indígenas, plasman una dimensión colectiva en el ejercicio de sus derechos ${ }^{55}$.

A propósito de ello cabe recordar que durante la celebración de la Cumbre de Jefes de Estado en Río de Janeiro (Brasil) en 1992 se suscribió el primer tratado multilateral que abordaba la biodiversidad como un asunto de importancia mundial, como lo fue el Convenio «sobre la diversidad biológica» ${ }^{56}$. En él ya se advertía la relación intrínseca de las «poblaciones» indígenas con la diversidad biológica que habitaba en sus territorios (apdo. 12 del Préambulo), siendo, en ese sentido, deber del Estado

Convención para la Protección de Minorías Nacionales (Consejo de Europa, 1998); la Declaración de la Conferencia Mundial contra el Racismo, la Discriminación Racial, la Xenofobia y las Formas Conexas de Intolerancia de 2001, de cuyas disposiciones se desprenden las atinentes a la «homogeneización cultural» entre los efectos que deben ser prevenidos y mitigados; la Convención para la Salvaguardia del Patrimonio Cultural Inmaterial (UNESCO, 2003); la OG 11 (2009) del Comité de los Derechos del Niño, concerniente a la situación de los/as niños/as indígenas, en línea con la Convención sobre los Derechos del Niño de 1989 (primer tratado en materia de derechos fundamentales en hacer referencia a los/as niños/as indígenas, aunque ha recibido críticas, como las del especialista peruano Wilfredo Ardito, por tener una óptica de la «autonomía» ajena a las realidades indígenas, es decir, a su carácter colectivo), y la OG 24 (2017) del Comité de Derechos Económicos, Sociales y Culturales (DESC) sobre «las obligaciones de los Estados en virtud del Pacto Internacional de Derechos Económicos, Sociales y Culturales en el contexto de actividades empresariales», en cuya oportunidad manifestó la importancia —en casos de actividades empresariales y sus «consecuencias adversas y reales sobre los derechos a la tierra, los recursos, los territorios, el patrimonio cultural, los conocimientos tradicionales y la cultura de los pueblos indígenas»- de que las empresas realicen (cabe recordar que por ello los Estados no se pueden eximir de responsabilidad) consultas con las comunidades originarias «a fin de obtener su consentimiento libre, previo e informado antes de iniciar cualquier actividad» (apdo. 17). Vid., entre otros, M. Gomiz y J. SALGado, Convenio 169 de la OIT sobre pueblos indígenas. Su aplicación en el Derecho interno argentino, 2. ${ }^{a}$ ed., Neuquén (Argentina), Observatorio de Derechos Humanos de los Pueblos Indígenas, 2010, pp. 82-94, disponible en https://www.iwgia.org/images/ publications/ILO_argentina_text.pdf (consultado el 26 de noviembre). Sobre dicha plataforma jurídica no se deben soslayar tampoco los aportes de la Carta de la ONU de 1945 [v.gr., arts. 1.3 y 13.1.b), relativos al «desarrollo y estímulo de los derechos humanos sin distinción de raza, sexo, idioma o religión» y, fundamentalmente, los arts. 55 y 56 que se erigen, dentro del ámbito de la cooperación internacional económica y social, con la finalidad de respetar el principio de la igualdad de los derechos y el de «la libre determinación de los pueblos»] ni los de la Declaración Universal de Derechos Humanos de 1948 ( $v$. gr., art. 2, en cuanto toda persona «tiene los derechos y libertades proclamadas sin distinción alguna de raza, color, sexo, idioma, religión, opinión política o de cualquier otra índole»).

${ }^{55}$ Cabe destacar que las distintas manifestaciones jurídicas que con el devenir del tiempo, han ido ponderando los aspectos «colectivos» de sus destinatarios/as han sido consecuencia de los movimientos indígenas — a nivel nacional e internacional—; fenómeno que no han atestiguado otros sectores vulnerables. En efecto, la presencia de estos actores deja entrever la doble dimensión de lo normativo, esto es, ya no solo como un producto, sino también como un proceso.

${ }_{56} \mathrm{El}$ mismo fue ratificado por Argentina en el año 1994 por medo de la Ley 24.375.

Foro, Nueva época, vol. 23, núm. 2 (2020): 183-233 
Parte respetar, preservar y mantener «los conocimientos, las innovaciones y las prácticas de las comunidades indígenas» [art. 8.j) $]^{57}$.

Pues bien, en lo tocante al Convenio 169 -el cual fue producto de una ardua labor por parte del organismo especializado de la ONU— ${ }^{58}$ cabe poner de relieve que este instrumento vincula sociológicamente «dos ejes muy importantes: clase y etnia» ${ }^{59}$, por ser «entre los sectores más explotados de trabajadores (sobre todo en el área rural) los indígenas» $»^{60}$, constituyéndose, de ese modo, en el primer instrumento internacional en regular y reconocer la diversidad cultural.

De tal suerte, y en lo que se refiere a su articulado - que difiere de la orientación asimilacionista ${ }^{61}$ de su predecesor, el Convenio $107-{ }^{62}$,

57 Disponible en https://www.cbd.int/doc/legal/cbd-es.pdf (consultado el 30 de noviembre de 2020). Al respecto, la Corte Interamericana de Derechos Humanos ha tomado nota en varios de sus pronunciamientos (vid. caso Pueblos Kaliña y Lokono c. Surinam, apdo. 177) de la mentada disposición normativa.

58 Así, a modo ilustrativo, podemos citar algunos antecedentes que datan de 1921 (donde el organismo comenzó a abordar la situación de los denominados «trabajadores indígenas» en las colonias de las potencias europeas) como también de 1926 (con la creación del comité de expertos en trabajo nativo), siendo este último el punto de partida para que se concierten distintos convenios, tales como el Convenio 29 sobre «trabajo forzoso» (1930), el Convenio 50 sobre el «reclutamiento de trabajadores indígenas» (1936) y el Convenio 64 sobre los «contratos de trabajo de trabajadores indígenas» (1939). Este panorama, a través de un comité de expertos creado en 1945, cimentó las bases del primer instrumento medular - en cuanto a derechos de los pueblos indígenas concierne- como lo fue el reformado Convenio 107 sobre «poblaciones indígenas, tribales y semitribales en países independientes» (1957). Vid. M. Gomiz y J. SALgado, Convenio 169 de la OIT sobre pueblos indígenas..., op. cit., pp. 30-31.

59 J. E. R. ORdóÑEz Cifuentes, Cuadernos constitucionales México-Centroamérica 30. La opinión consultiva de la Corte de Guatemala sobre la constitucionalidad del Convenio 169. Una experiencia constructiva en favor de la paz, República de Guatemala, Centro de Estudios Constitucionales México-Centroamérica-Instituto de Investigaciones Jurídicas-Universidad Nacional Autónoma de México-Corte de Constitucionalidad, 1998, p. 123 (capítulo VIII, «Otras disposiciones de la OIT vinculadas a los derechos de los pueblos indígenas»), disponible en https://biblio.juridicas.unam.mx/bjv/detalle-libro/123-cuadernos-constitucionales-mexico-centroamerica-30-la-opinion-consultiva-de-la-corte-de-guatemalasobre-la-constitucionalidad-del-convenio-169-de-la-oit-una-experiencia-constructiva-en-favorde-la-paz (consultado el 28 de noviembre de 2011).

${ }_{60}$ Ibid. nota 58.

${ }^{61}$ Siguiendo la línea de pensamiento de la antropóloga mexicana Alicia Barabas, quien, con la finalidad de determinar si el imaginario sobre el bárbaro desde la época colonial forma parte de las representaciones actuales sobre los indígenas, realiza un racconto histórico de lo acaecido en México, podemos relacionar este concepto (asimilacionismo) con el de «indigenismo» (particularmente el de «incorporación» que se presentó luego de 1940), en tanto se buscaba «construir un Estado nacional étnica y culturalmente homogéneo, por lo que la pluralidad cultural interna era vista como un obstáculo para el desarrollo». Además, agrega que, tras la celebración del Primer Congreso Indigenista en Pátzcuaro (Michoacán, México), el indigenismo de entonces («de incorporación») se tornaría en uno de «integra- 
nos abocaremos a los derechos de índole colectivo que dicho instrumento contempla.

En primer lugar cabe recordar que, como señalan María Gomiz y Juan Manuel Salgado, una de las notas características del instrumento se deriva en ser el primero en reconocer de forma expresa «la dimensión colectiva en el ejercicio de los derechos» ${ }^{63}$.

En ese tenor, y con el objeto de precisar la mirada diferencial que estos derechos (colectivos) demandan, atenderemos a la línea de pensamiento de Miguel Benedetti, quien cavila que hay tres zonas indivisiblemente claves en lo que a ellos (derechos colectivos) atañe. Así, da cuenta de las áreas «política» (autonomía, participación, consulta), «territorial» (propiedad comunitaria) y «cultural» (derechos lingüísticos, culturales, religiosos), todo ello bajo el halo del principio «propersona» del art. $35^{64}$ (léase «proindígena»).

En referencia a la primera de ellas (política), el tratado, estableciendo la conciencia de la identidad indígena o tribal como «criterio fundamental» a los fines de aplicar sus disposiciones (art. 1.2), reconoce el derecho de las comunidades indígenas a su «autonomía», siendo así que, cualquiera que sea su situación jurídica, conservan sus «instituciones sociales, económicas, culturales y políticas» ${ }^{65}$ [art. 1.1.b)], en tanto —al igual que

ción», promoviéndose, de ese modo, «las costumbres y tradiciones "positivas" de los indígenas» $(v, g r$, productos artesanales, danzas y música, es decir, «los aspectos culturales no ofensivos para los "civilizados"»). Vid. en tal sentido A. BARABAS, «La construcción del indio como bárbaro: de la etnografía al indigenismo», Alteridades, núm. 10 (2000), p. 15, disponible en https://alteridades.izt.uam.mx/index.php/Alte/article/viewFile/420/419 (consultado el 12 de diciembre de 2020). Por lo que, en atención también a la línea reflexiva del antropólogo norteamericano Marshall Sahlins, la categoría «indigenismo» tiene una connotación peyorativa en relación con los pueblos indígenas y no es una herramienta reivindicatoria «pro-indígena». sino, por el contrario, constituye una estrategia de los «vencedores sobre los vencidos».

${ }^{62}$ Uno de los agregados medulares del Convenio 169 es que versa sobre «derechos humanos fundamentales» (apdo. 6 del Preámbulo), mientras que el Convenio 107 —redactado sin participación indígena y sin ponderar la «libre determinación» de las comunidades originarias, que no eran vistas como sujetos de derechos colectivos ni contaban con «autoidentificación»— estaba dirigido a «orientar las políticas sociales» de los pueblos indígenas, donde estas últimas eran sinónimo de «atraso». Vid. M. Gomiz y J. Salgado, Convenio 169 de la OIT sobre pueblos indígenas..., op. cit., pp. 37-54.

${ }_{63}$ Ibid., p. 79.

${ }^{64}$ El mismo determina que la aplicación de las disposiciones del tratado «no deberá menoscabar los derechos y las ventajas garantizadas a los pueblos interesados en virtud de otros convenios y recomendaciones, instrumentos internacionales, tratados o leyes, laudos, costumbres o acuerdos nacionales».

${ }^{65}$ A propósito de ello es dable recordar que los pueblos indígenas tienen derecho — que deberá ser reconocido por los respectivos gobiernos- a crear sus propias insti- 
sus costumbres- ${ }^{66}$ no sea incompatibles con «los derechos fundamentales definidos en el sistema jurídico nacional ni con los derechos humanos internacionalmente reconocidos» (art. 8.2). Por su parte, los gobiernos deberán coadyuvar — sin contrariar los deseos «expresados libremente por los pueblos» (art. 4.2) - en el ejercicio de este derecho autonómico mediante acciones coordinadas — con las mismas comunidades indígenas - a fin de «proteger los derechos de los pueblos y a garantizar el respeto de su integridad» (art. 2.1).

De igual modo, a los efectos de aplicar las previsiones normativas ${ }^{67}$, el tratado explicita la necesidad de la «participación» indígena, constituyendo, por tanto, un deber de los gobiernos prever «procedimientos apropiados» con el objeto de que los pueblos (mediante sus instituciones representativas) participen en aquellas cuestiones que puedan «afectarles directamente» [art. 6.1.a)], tales como los casos «medioambientales» sobre sus territorios (art. 7.4) o en lo que respecta a sus recursos naturales. A su vez, el rol activo de las comunidades (a través de su cooperación) se ve plasmado en asuntos impostergables de salubridad, en tanto que los servicios de salud deberán reparar en los rasgos característicos de los pueblos («su condiciones económicas, geográficas, sociales y culturales, así como sus métodos de prevención, prácticas curativas y medicamentos tradicionales») (art. 25.2).

tuciones educativas y medios de comunicación, siempre que se respeten los estándares mínimos normativos que establezca la autoridad competente «en consulta con los pueblos» (art. 27.3).

${ }^{66}$ En ese sentido, los gobiernos deberán velar por la protección de todas las actividades que constituyan los modos de subsistencia ( $v$. gr., pesca, caza o artesanía, entre otros) de la comunidad de que se trate y que, en última instancia, son los cimientos para el mantenimiento «de su cultura y de su autosuficiencia y desarrollo económicos» (art. 23.1). En esta idea «deberán protegerse especialmente» los derechos (de utilización, administración y conservación) correspondientes a las comunidades sobre los recursos naturales que subyacen en sus territorios (art. 15.1). Aún más, en caso de establecerse que algunos recursos sean de dominio público estatal, los mismos no podrán disponerse sin consulta previa a los pueblos, participando estos, además y en caso de llevarse a cabo programas de «prospección o explotación», de los beneficios de tales actividades, con derecho a una indemnización equitativa a los daños que se les pudiera causar (art. 15.2).

${ }^{67} \mathrm{Al}$ respecto, los gobiernos deberán adoptar todas aquellas medidas necesarias, con la ineludible participación de las comunidades originarias, para «allanar las dificultades» que las mismas atraviesan, por ejemplo, en sus condiciones de vida y de trabajo [art. 5.c)]. Precisamente a esos efectos, los gobiernos deberán establecer — con la participación de los pueblos- medidas legislativas que tiendan a una especial protección, en particular en materia de «contratación y condiciones de empleo» (art. 20.1), así como también propender — con la colaboración de las comunidades- la formación profesional de sus miembros (art. 22.1). 
En sí, y ante este panorama normativo (participación), no se puede soslayar - más aún en el marco del derecho colectivo a sus tierras y territorios- el requisito (esencial) del consentimiento que deben prestar «libremente» las comunidades en los casos de su traslado y posterior reubicación, resultando imprescindible, en caso de no poder obtenerse aquel (consentimiento), fijar «procedimientos adecuados establecidos por la legislación nacional, incluidas encuestas públicas» (art. 16.2). Sin embargo, vale decir que los pueblos deberán tener el derecho, en la medida de su factibilidad - cuando dejen de existir las causas que motivaron el traslado-, de «regresar a sus tierras» (art. 16.3), en cuanto que, en caso de verse imposibilitados de retornar a sus tierras, se les deberá otorgar «tierras cuya calidad y cuyo estatuto jurídico sean por lo menos iguales a las tierras que ocupaban anteriormente» (art. 16.4).

En ese orden de ideas es menester reparar en la segunda de las áreas (territorial). En efecto, el tratado (en su «Parte II») dedica varias disposiciones a la materia «tierras» ${ }^{68}$, estableciendo que los gobiernos deberán tomar en consideración las distintas connotaciones que en la relación con sus tierras o territorios ( $v . g r$., valores espirituales) le otorguen las comunidades, en particular «los aspectos colectivos de esa relación» (art. 13.1), debiéndose reconocer, a tenor de lo dispuesto, el «derecho de propiedad y de posesión sobre las tierras que tradicionalmente ocupan» (art. 14.1). En esa inteligencia normativa, los gobiernos deberán garantizar, a su vez, el derecho de propiedad comunal que ostenten las comunidades (art. 14.2), máxime cuando se erijan reclamos, en cuyo caso los gobiernos deberán instituir, dentro de su ordenamiento jurídico, «procedimientos adecuados» que viabilicen (solucionen) dichas reivindicaciones (art. 14.3). De manera similar, resulta destacable el deber de los gobiernos de salvaguardar este derecho comunal, ya no solo por el cauce del respeto (en la relación de las comunidades hacia sus tierras y territorios), sino también respecto a terceros que interfieran en el ejercicio de este derecho, tanto en casos de «toda intrusión no autorizada» — que deberá dar lugar a las sanciones correspondientes- (art. 18) como de aprovechamiento «de las costumbres de esos pueblos o de su desconocimiento de las leyes» (art. 17.3).

${ }^{68}$ En ese entendimiento, el decálogo determina que la utilización de tierras (en aquellos supuestos que versen sobre recursos naturales, así como del traslado y reubicación de las comunidades) «deberá incluir el concepto de territorio», cubriendo, por ende, «la totalidad del hábitat de las regiones que los pueblos interesados ocupan o utilizan de alguna otra manera» (art. 13.2). 
Finalmente, en lo que hace a la edificación de la tercera área (cultural), se advierten varios pasajes normativos del convenio. Así, por ejemplo, el instrumento se refiere a los derechos «culturales», puntualizando el rol activo de los gobiernos en la promoción «efectiva» de los «derechos económicos, sociales y culturales» respetando, en tal sentido, «su identidad social y cultural, sus costumbres y tradiciones, y sus instituciones ${ }^{69}$ [art. 2.2.b)]. Ello, en cuanto los gobiernos, con miras a «materializar» (léase efectivizar) las disposiciones del instrumento internacional ${ }^{70}$, deberán reparar en los «valores y prácticas sociales, culturales, religiosas y espirituales propias de dichos pueblos», atendiendo, en consecuencia, los inconvenientes que se les plantean «tanto colectiva como individualmente» [art. 5.a) $]^{71}$.

Bajo esos parámetros (culturales) caben mencionar, además, los derechos educativos $^{72}$ que asisten — «en pie de igualdad con el resto de la comunidad nacional» (art. 26) — a los/as niños/as indígenas, en vista de los cuales se les deberán impartir «conocimientos generales y aptitudes que les ayuden a participar plenamente» en la vida de su propia comunidad y en la comunidad nacional (art. 29).

No es ocioso recordar, en esta dirección, los denominados derechos «lingüísticos», sopesados por el tratado, en cuanto este establece la adecuación de la educación que reciban los/as niñas indígenas manteniendo incólumes «su propia lengua indígena o la lengua que más comúnmente se hable en el grupo al que pertenezcan» (art. 28.1). Añade el decálogo que, en caso de no ser asequible dicha adaptabilidad de la enseñanza, «se deberán celebrar consultas con esos pueblos» con el objeto de franquear aquel óbice (art. 28.1) ${ }^{73}$.

Ahora bien, cabe recordar que años más tarde, el 13 de septiembre de 2007, se elaboró otro hito en la materia como fue la UNDRIP ${ }^{74}$, la cual

${ }^{69}$ Se sigue de ello que los pronunciamientos en el ámbito penal - tanto administrativo como judicial— «deberán tener en cuenta las costumbres de dichos pueblos en la materia» (art. 9.2).

${ }^{70}$ Como, a su vez, en los casos en que se debe aplicar su «legislación nacional» (art. 8.1).

${ }^{71}$ Otras disposiciones relativas a la esfera cultural son los ya mencionados arts. 8.2, 13.1, 17.1 y 25.2 .

${ }_{72}$ Esta clase de derechos - al igual que los que conciernen a los pueblos en la esfera laboral, económica y sanitaria, entre otros-, deberán darse a conocer — como sus obligaciones- de conformidad a sus «tradiciones y culturas» (art. 30.1), para lo cual deberá recurrirse, en caso de ser necesario, a «traducciones escritas y a la utilización de medios de comunicación de masas en las lenguas de dichos pueblos» (art. 30.2).

${ }^{73}$ Esto de conformidad con el objetivo del convenio de «preservar las lenguas indígenas» (art. 28.3)

${ }^{74}$ Entre sus antecedentes es dable mencionar la Convención sobre la Protección y Pro- 
se cimentó en la intensa tarea del grupo de trabajo «sobre el proyecto de declaración sobre los derechos de los pueblos indígenas» ${ }^{75}$, en conjunto con los «pueblos indígenas y sus dirigentes en la ONU y también con representantes del Estado y de la sociedad civil» ${ }^{76}$.

En sí, este decálogo — cuya trascendencia, como instrumento esencialmente reparatorio, la constituye el hecho de ser «la primera norma internacional centrada sobre todo en el reconocimiento de derechos colectivos» ${ }^{77}$, perfilándose, de esa manera, en un «medio idóneo para la efectiva rea-

moción de la Diversidad de las Expresiones Culturales de 20 de octubre de 2005, de la cual se desprendían únicamente someras referencias a la cuestión indígena (pueblos «autóctonos», conforme la literatura del texto). De tal forma, reconoce la importancia de los conocimientos tradicionales, en particular «los sistemas de conocimiento de los pueblos autóctonos» (apdo. 8 del Preámbulo), así como la importancia vital de «las culturas para todos, especialmente en el caso de las personas pertenecientes a minorías y de los pueblos autóctonos» (apdo. 15 del Preámbulo). Más aún, establece como principios rectores, en el ámbito de los derechos humanos, el respeto de la «dignidad y de todas las culturas» - entre las que se encuentran las minorías y los pueblos autóctonos (cfr. art. 2.3) - Y es en esa inteligencia normativa donde, a su vez y como deberes de los Estados, determina el de «incitar», dentro de su territorio, a las diversas expresiones culturales provenientes - entre otros supuestos- de las «minorías y los pueblos autóctonos» [art. 7.1.a)]. Vid. http://www.unesco. org/new/es/culture/themes/cultural-diversity/cultural-expressions/the-convention/conventiontext/ (consultado el 30 de noviembre de 2020).

${ }_{75}$ El mismo, que se estableció por medio de la Resolución 1995/32 de la Comisión de Derechos Humanos (actual Consejo de Derechos Humanos desde el 15 de marzo de 2006) y la Resolución 1995/32 del Consejo Económico y Social (cfr. arts. 61 y ss. de la Carta de la ONU de 1945), tenía por único objetivo elaborar — como su denominación indicaun proyecto de declaración sobre los derechos de los pueblos indígenas (acúdase, interés mediante, a su Informe E/CN.4/2006/79, de 22 de marzo de 2006, en cuya oportunidad el organismo, haciendo hincapié en la participación indígena, concluyó la «preocupación» de once Estados ante la falta de consenso en cuestiones tan sensibles y fundamentales como lo eran «la libre determinación», «las tierras», «los recursos» y «la naturaleza de los derechos colectivos»). Vid. https://www.ohchr.org/SP/Issues/IPeoples/Pages/WGDraftDeclaration. aspx (consultado el 29 de noviembre de 2020).

76 A. Williensen-Díaz, «Cómo llegaron los derechos de los pueblos indígenas a la ONU», en C. Charters y R. Stavenhagen (eds.), El desafío de la declaración. Historia y futuro de la declaración de la ONU sobre pueblos indígenas, Copenhague, IWGIA, 2010, pp. 16-33, esp. pp. 20-21, disponible en https://books.google.com.ar/books?hl=es $\mathcal{E l}$ $r=\varepsilon i d=v b U i j K B 7$ th 8 CEoi $=$ fndE $p g=P A 10 \xi d q=$ CHARTERS, + Claire $+\% E 2 \% 80 \% 93+$ Rodolf o+STAVENHAGEN+(Editores).+Desaf\%C3\%ADos+de+la+Declaraci $\%$ C3\%B3n + +Historia + $y+$ futuro + de + la + declaraci $\% C 3 \% B 3 n+d e+l a+O N U+$ sobre + pueblos + ind $\% C 3 \%$ ADgenas,$+C o$ penhague, $+I$ WGIA, +2010 Eots=2NBe7d_YlkEsig=BSViQnkwS_g4OLPfakyopk6Mjg8Eredir_ esc $=y \# v=$ onepage $\mathrm{E} q=$ CHARTERS $\% 2$ C $\%$ 20Claire $\% 20 \%$ E2\% $80 \% 93 \% 20$ Rodolfo $\% 20$ STA VENHAGEN\%20(Editores).\%20Desaf\%C3\%ADos\%20de\%20la\%20Declaraci\%C3\%B3n. \%20Historia\%20y\%20futuro\%20de\%20la\%20declaraci\%C3\%B3n\%20de\%20la\%20ONU $\% 20$ sobre\%20pueblos \%20ind\%C3\% ADgenas \%2C\%20Copenhague\%2C\%20IWGIA\%2C $\% 202010 \varepsilon f=$ false (consultado el 30 de noviembre de 2020).

77 A. CARMEN, «Informe desde el campo de batalla del Consejo Internacional de Tratados Indios: la lucha por la Declaración», en C. CHARTERS y R. STAVENHAgen (eds.), El desafío 
lización de muchos de los derechos humanos individuales consagrados universalmente»- ${ }^{78}$ puso de relieve otro de los aspectos atípicos que circunscribe la esfera indígena, esto es, el hecho de que un tratado (Convenio 169) se lleve a cabo de forma previa a una declaración.

Por otra parte, en cuanto a su naturaleza jurídica, nos adherimos a la postura de quien fuera miembro del Foro Permanente para Cuestiones Indígenas de la ONU, Bartolomé Clavero (citado por Luis Rodríguez-Piñero Royo), el cual pone de relieve, pese al sustrato inherente del instrumento (como declaración), que la misma debe ser considerara de carácter vinculante en tanto cuenta, al igual que acaece con los tratados internacionales y sus órganos supervisores, con un órgano de contralor -el Foro Permanente- ${ }^{79}$, con la particularidad de que no está previsto en su articulado. A ello añade lo contemplado en el art. 42 del mencionado instrumento, a saber, la participación de actores internacionales y Estados para promover el respeto de la declaración, utilizando el término «de plena aplicación», lo cual trascendería de una mera cuestión semántica ${ }^{80}$.

Entonces, en consonancia con lo expuesto, cabría resaltar que el instrumento no es un mero catálogo de derechos, sino que, por el contrario, deviene legítimo por su «contenido sustantivamente justo» (v. gr., optimiza la justicia del Derecho internacional garantizando un lugar a los pueblos indígenas), por mejorar «la coherencia y precisión de los derechos de los pueblos indígenas» ( $v . g r$, clarificando los derechos de estos pueblos y

de la declaración. Historia y futuro de la declaración de la ONU sobre pueblos indígenas, Copenhague, IWGIA, 2010, pp. 90-101, esp. p. 98.

${ }^{78}$ A. Regino Montes y G. Torres Cisneros, «La Declaración de las Naciones Unidas sobre los derechos de los pueblos indígenas: base de la nueva relación entre los pueblos indígenas, los Estados y las sociedades», en C. CHARTERS y R. STAVENHAGEN (eds.), El desafío de la declaración. Historia y futuro de la declaración de la ONU sobre pueblos indígenas, Copenhague, IWGIA, 2010, pp. 146-177, p. 168.

${ }^{79}$ Cabe recordar que el órgano - el único con representación paritaria- constituye uno de los tres mecanismos de la ONU dedicados a cuestiones específicas de los pueblos indígenas (los dos restantes están compuestos por el Mecanismo de Expertos sobre los Derechos de los Pueblos Indígenas y el Relator Especial sobre los Derechos de los Pueblos Indígenas), instituyéndose (como órgano asesor del ECOSOC) el 28 de julio de 2000 por la Resolución 2000/22, disponible en https://www.un.org/development/desa/indigenous-peoples-es/sesiones-del-foro-permanente.html (consultado el 16 de diciembre de 2020).

${ }^{80}$ En ese tenor resulta cardinal la «legitimidad» que ostenta el decálogo en razón de haber contado con la participación de las comunidades indígenas para su elaboración. Vid. L. RODRíguez-PIÑERo RoYo, «"Cuando proceda": vigilancia y aplicación de los derechos de los pueblos indígenas según la declaración», en C. CHARTERS y R. STAVENHAGEN (eds.), El desafio de la declaración. Historia y futuro de la declaración de la ONU sobre pueblos indígenas, Copenhague, IWGIA, 2010, pp. 336-365, esp. pp. 338-339. 
otorgándole a los mismos cierta nitidez a su campo de aplicación, como se verifica con «libre determinación de los pueblos») y por ser el resultado «de procesos legítimos» (v. gr., en sus compromisos, la participación abierta en sus discusiones, etc. $)^{81}$.

Otro argumento a favor del carácter vinculante de la UNDRIP 82 podría encontrar basamento en el hecho de ser, en última instancia, los diversos órganos supervisores de los tratados internacionales en el ámbito de la ONU (v. gr., Comité de Derechos Económicos, Sociales y Culturales) los que realicen interpretaciones de tal instrumento y, por tanto, sus disposiciones se plasmarán en las funciones que aquellos órganos desplieguen.

Frente a tal panorama, y siguiendo la orientación estipulada (áreas «política», «territorial»y «cultural»), es menester adentrarnos en su articulado, que encuentra en la «libre determinación» (art. 3$)^{83}$ su directriz sustancial.

En referencia al ámbito «político» de sus derechos cabe mencionar el de la «autonomía» (o autogobierno), cuyo ejercicio se encuentra inescindiblemente vinculado con el derecho a la «libre determinación» (cfr. art. 4). Se deduce de ello que el derecho a la autonomía resulta cardinal para los siguientes ejes de la vida cotidiana de los pueblos: asuntos internos ${ }^{84}$ y locales — y todo lo concerniente a la disposición de recur-

${ }^{81}$ Es decir, posee una cualidad que lleva a que los Estados interioricen «un impulso de obedecer esas normas de manera voluntaria y habitual». Vid. C. CHARTES, «La legitimidad de la Declaración de la ONU sobre los Derechos de los Pueblos Indígenas», en C. CHARTERS y R. Stavenhagen (eds.), El desafío de la declaración. Historia y futuro de la declaración de la ONU sobre pueblos indígenas, Copenhague, IWGIA, 2010, pp. 301-320.

${ }^{82}$ A su vez, podría esgrimirse que la obligatoriedad de la UNDRIP reside en el denominado instituto (de origen anglosajón) del «estoppel» (de los actos propios). En otras palabras, y siguiendo los postulados de esta doctrina, si el Estado consintió firmar no puede retractarse. En correspondencia con ello apélese al apartado 44 («por tanto, la Corte considera que el Estado implícitamente ha renunciado a su derecho de cuestionar la admisibilidad del caso») de la Corte Interamericana de Derechos Humanos en el caso - que se detallará seguidamente-Pueblo Saramaka c. Surinam, de 28 de noviembre de 2007, del cual — reputamos - se desprende el denominado «estoppel by silence» (aquiescencia). Acúdase, a los fines de ahondar sobre el instituto aquí señalado, al trabajo de F. J. VASALLO, «El estoppel: dificultades para definir una regla en Derecho internacional y el rol deslucido de la Corte Internacional de Justicia», Lecciones y Ensayos, núm. 91 (2013), p. 183, disponible en bttp://www.derecho.uba.ar/ publicaciones/lye/revistas/91/el-estoppel-dificultades-para-definir-una-regla-en-derecho-internacional-y-el-rol-deslucido-de-la-corte-internacional-de-justicia.pdf (consultado el 27 de noviembre de 2020).

${ }_{83}$ El mismo reza que los pueblos indígenas «tienen derecho a la libre determinación. En virtud de ese derecho determinan libremente su condición política y persiguen libremente su desarrollo económico, social y cultural» (art. 3).

${ }^{84}$ Por ejemplo, «determinar las responsabilidades» de sus miembros (art. 35). 
sos económicos ${ }^{85}$ de las comunidades (art. 4) ${ }^{86}$-; el desarrollo y mantenimiento de sus instituciones ${ }^{87}$ — políticas, jurídicas, económicas, sociales y culturales, y la participación de sus miembros-; en la vida política, económica, social y cultural del Estado ${ }^{88}$ (art. 5); determinar - y ejercitar (cfr. art. 23, primera parte)— su derecho al desarrollo o la «utilización de sus tierras o territorios y otros recursos» (art. 32.1); promover, desarrollar y mantener «sus propias costumbres, espiritualidad, tradiciones, procedimientos y prácticas» (art. 34); mantener —en caso de encontrarse divididos por fronteras internacionales - todos aquellos lazos inherentes (espiritual, cultural, etc.) entre sus miembros «así como con otros pueblos» (art. 36.1).

En lo tocante a la «participación» se infiere que su ejercicio es necesario para la toma de aquellas decisiones que puedan repercutir ${ }^{89}$ en los derechos de las comunidades ${ }^{90}$. Con ese fin, y de conformidad con sus procedimientos, los pueblos contarán con sus propios «representantes» (art. 18); se les facilitará el acceso o restitución de «objetos de culto y de restos humanos» (art. 12.2); derecho a la educación, en todos sus ciclos, de los/as niños/as de las comunidades «sin discriminación» (art. 14.2); la adopción de medidas con miras a erradicar las distintas «formas de violencia y discriminación» que pudieran sufrir las mujeres y los/as niños/as indígenas (art. 22.2); el reconocimiento y adjudicación —que debe reconocer debidamente «las leyes, tradiciones, costumbres y sistemas de tenencia»- de los derechos de los pueblos indígenas con sus tierras, territorios y recursos (art. 27); la elaboración de programas que coadyuven al «control, mantenimiento y restablecimiento de la salud de los pueblos» en aquellos supuestos de utilización de materiales peligrosos en sus tierras o territorios (art. 29.3); la adopción de las medidas que disponga el Estado con la finalidad de proteger los derechos de los pueblos a «su patrimonio cultural, sus conocimientos tradicionales y sus expresiones culturales tra-

${ }^{85}$ Como, a su vez, para el ejercicio de su «derecho al desarrollo» (art. 23, primera parte).

${ }^{86}$ Ello en línea con el art. 20, que dispone el derecho de los pueblos indígenas «a mantener y desarrollar sus sistemas o instituciones» como a «disfrutar de forma segura de sus propios medios de subsistencia».

${ }^{87}$ De conformidad «con sus propios procedimientos» (art. 33.2).

${ }^{88}$ Cabe decir, bajo dicha enunciación normativa, que los Estados deben respetar todos aquellos «tratados, acuerdos y otros arreglos que acuerde con las comunidades originarias» (art. 37).

${ }_{89}$ Tal es el caso de los «programas de salud y vivienda» (art. 23, segunda parte).

${ }^{90}$ En el supuesto de verse quebrantados sus derechos, las reparaciones se deberán determinar teniendo en cuenta la participación de las comunidades (art. 11.2). 
dicionales» (art. 31) y, además, para velar por el cumplimiento del presente decálogo (art. 41).

En esa sintonía, y en torno al derecho a la «consulta» ${ }^{91}$, el instrumento establece que se debe contar con este derecho - «por medio de sus instituciones representativas»— en aquellos supuestos en los que: el Estado adopte y aplique medidas legislativas o administrativas que afecten a las comunidades «a fin de obtener su consentimiento libre, previo e informado» (art. 19); se elaboren políticas «para combatir los prejuicios y eliminar la discriminación y promover la tolerancia» (art. 15.2); se tomen medidas para «proteger a los niños indígenas contra la explotación económica y contra todo trabajo que pueda resultar peligroso o interferir en la educación de los niños» (art. 17.2); se les consulten «antes de utilizar sus tierras o territorios para actividades militares» (art. 30.2); sea necesario obtener su consentimiento libre e informado antes de aprobar «cualquier tipo de proyecto que afecte a sus tierras o territorios y otros recursos» (art. 32.2); se busque adoptar medidas - si las comunidades se encontraren separadas por fronteras - para facilitar el ejercicio del derecho a «mantener y desarrollar» las relaciones de sus miembros con las comunidades y/o con otros pueblos (art. 36.2), como también en aquellas ocasiones en las que los Estados propendan a adoptar medidas con la finalidad de alcanzar «los fines de la presente Declaración» (art. 38).

No se debe soslayar que, como se observa en la disposición del citado art. 19, el decálogo prevé la obligación de contar con el «consentimiento libre, previo e informado» en aquellos presupuestos donde: las comunidades sean trasladadas con «un acuerdo previo sobre una indemnización justa y equitativa» (art. 10); al proporcionar una reparación que incluya la restitución de bienes culturales, religiosos y espirituales de los que «hayan sido privados sin su consentimiento libre, previo e informado» (art. 11.2); se busque reparar ${ }^{92}$ a las comunidades que fueron despojadas de sus tierras, territorios y recursos «sin su consentimiento libre, previo e informado» (art. 28.1); se tienda a asegurar que no se «almacenen ni eliminen materiales peligrosos» en sus tierras o territorios (art. 29.2), y sustancialmente en aquellos supuestos en los que se requiera de la aprobación de

91 Cabe recordar que la misma forma parte de la autonomía «externa».

92 Cuando no sea posible la restitución de las tierras, territorios y recursos, la indemnización de la que resulten destinatarios los pueblos consistirá — salvo acuerdo en contrario ( v. gr., compensación monetaria) - en «tierras, territorios y recursos de igual calidad, extensión y condición jurídica» (art. 28.2), siendo, a tal efecto, ineludible el deber de los Estados de contar con «mecanismos eficaces» [cfr. art. 8.2.b)]. 
proyectos —en especial los referidos a la explotación de recursos minerales- que puedan llegar a afectar «sus tierras o territorios» (art. 32.2).

En lo que concierne a la esfera «territorial» ${ }^{93}$ de los pueblos indígenas, este derecho es de observar en diversos pasajes normativos del decálogo, ya sea a los efectos de mantener y fortalecer sus lazos espirituales «con las tierras, territorios, aguas, mares costeros y otros recursos que tradicionalmente han poseído» (art. 25); respecto al derecho del que devienen titulares las comunidades a «las tierras, territorios y recursos que tradicionalmente han poseído, ocupado, utilizado o adquirido ${ }^{94}$ (art. 26.1); al deber de los Estados de asegurar mecanismos eficaces para la prevención y resarcimiento frente a todo acto que persiga - o tenga como consecuencia- desposeer a los pueblos indígenas de sus «tierras, territorios o recursos» [art. 8.2.b)], en tanto que, en ningún caso, los mismos serán desplazados de sus tierras o territorios «por la fuerza» (art. 10); en relación con el derecho a «la conservación y protección del medio ambiente y de la capacidad productiva de sus tierras» (art. 29.1); con miras a que no se realicen actividades militares, siempre que, desde luego, no «lo justifique una razón de interés público» (art. 30.1), y al consentimiento libre, previo e informado en aquellos proyectos que afecten a «sus tierras y territorios» (art. 32.2).

Finalmente, en ese orden de cosas caben reputar algunas disposiciones de la declaración atinentes a la esfera «cultural» de las comunidades originarias y a los derechos que esta atañe, tales como: a que los pueblos y sus miembros no sean «sometidos a una asimilación forzada ni a la destrucción de su cultura» (art. 8.1); a los mecanismos que deban establecer los Estados para prevenir y resarcir cualquier acto que «tenga por objeto o conse-

${ }^{93}$ En su momento, tras dos años de la aprobación de la UNDRIP, el Comité de Derechos Económicos, Sociales y Culturales (Comité DESC) en su OG 21, sobre el «Derecho de toda persona a participar en la vida cultural», receptaría estas variaciones internacionales en cuanto a los derechos colectivos de las comunidades originarias. $\mathrm{Al}$ respecto, y señalando el derecho - colectiva o individualmente - de dichas comunidades al «disfrute pleno de todos los derechos humanos y libertades fundamentales» por las normas internacionales (vid. apdo. 7), destacó que la dimensión colectiva de la vida cultural de los pueblos indígenas resulta «indispensable para su existencia, bienestar y desarrollo integral», comprendiendo «el derecho a las tierras, territorios y recursos que tradicionalmente han poseído, ocupado de otra forma, utilizado o adquirido» (apdo. 36). Vid. https://conf-dts1.unog.ch/1\%20SPA/ Tradutek/Derechos_hum_Base/CESCR/00_1_obs_grales_Cte\%20Dchos\%20Ec\%20Soc\%20 Cult.html\#GEN21 (consultado el 2 de diciembre de 2020).

${ }_{94}$ Ello, dado el derecho que revisten las comunidades a «poseer, utilizar, desarrollar o controlar» sus tierras, territorios y recursos (cfr. art. 26.2), lo cual debe ser reconocido y protegido por los «Estados» (art. 26.3) de conformidad con las «leyes, tradiciones, costumbres y sistemas de tenencia de los pueblos» (art. 27). 
cuencia privarlos de su integridad como pueblos distintos» ${ }^{95}$ [art. 8.2.a)]; a «practicar y revitalizar sus tradiciones y costumbres culturales» ${ }^{96}$, esto es, sus derechos a «mantener, proteger y desarrollar manifestaciones ${ }^{97}$ pasadas, presentes y futuras» (art. 11.1), para lo cual los Estados deben propender por el mantenimiento y protección de «sus lugares religiosos y culturales» (art. 12.1); a establecer y controlar todos aquellos aspectos vinculados a la educación que se imparta en sus idiomas, los cuales deben sujetarse a «su métodos culturales de enseñanza y aprendizaje» (art. 14.1) ${ }^{98}$; a que «la dignidad y diversidad de sus culturas, tradiciones, historias y aspiraciones» se encuentren «debidamente» reflejadas «en la educación y la información pública» ${ }^{99}$ (art. 15.1), siendo, con ese alcance, esenciales las medidas que adopten los Estados para «combatir los prejuicios y eliminar la discriminación y promover la tolerancia» (art. 15.2); al establecimiento de sus «propios medios de información en sus propios idiomas» y de «acceder a los demás medios de información no indígenas sin discriminación» (art. 16.1); a valerse de «sus propias medicinas tradicionales» como al acceso «sin discriminación alguna a todos los servicios sociales y de salud» (art. 24.1), y, entre otros, a «mantener, controlar, proteger y desarrollar su patrimonio cultural, sus conocimientos tradicionales y sus expresiones culturales tradicionales» (art. 31.1).

\section{NOTAS DEL SISTEMA INTERAMERICANO DE DERECHOS HUMANOS}

En esa sintonía, y siendo América Latina distinguida por su enorme diversidad cultural ${ }^{100}$, cabe poner de relieve lo acontecido en el sistema regional.

${ }_{95}$ Al igual que en aquellos casos que supusieran una «forma de asimilación o integración forzada» [art. 8.2.d)].

96 Estas deberán ser ponderadas a la hora de decidir en todos aquellos conflictos que atañen a los pueblos, en particular en lo que hace a la esfera colectiva (art. 40).

97 De igual modo, sus «lugares arqueológicos e históricos, diseños y ceremonias» (art. 11.1).

98 En ese sentido, los Estados adoptarán las medidas eficaces para que, cuando sea posible, los/as niños/s indígenas tengan acceso a la «educación en su propia cultura y en su propio idioma» (cfr. art. 14.3).

99 En este aspecto, los Estados deben asegurar que la «diversidad cultural» de los pueblos indígenas se encuentre plasmada en los medios de información pública (cfr. art. 16.2).

100 Interesa señalar, en línea con los datos obtenidos por la Comisión Económica para América Latina y el Caribe (CEPAL), que para el año 2014 existían más de 800 pueblos 
Así, es dable reparar primordialmente en la Declaración Americana sobre los Derechos de los Pueblos Indígenas (en adelante, DADPI), aprobada en el marco de la Organización de Estados Americanos (en adelante, OEA) el 15 de junio de 2016.

En ese sentido, y dada la inevitable comparación cronológica y sustancial ${ }^{101}$ con su par internacional (UNDRIP), nos abocaremos a algunas de las críticas que se han erigido en torno al instrumento regional, que ya se comenzaban a atisbar por su tardía aparición, en vista de haberse iniciado su proceso de elaboración en el año $1989^{102}$.

De tal forma, en atención a las reflexiones de la asesora legal del Grupo de Trabajo sobre Asuntos Indígenas Nancy Yañez, la DADPI, esgrimiendo cuestiones presupuestarias, dejó entrever la limitada participación indígena en su elaboración, en cuanto contaba con «un representante por cada una de las cuatro regiones que conforman las Américas» ${ }^{103}$.

Se sigue de ello, principalmente, que más allá del hecho de que el instrumento regional prevea los derechos medulares de los pueblos indí-

indígenas con cerca de 45 millones de personas, siendo que, en el periodo de 2000 a 2010, la población indígena aumentó un 49,3 por 100, lo que equivale a una tasa de crecimiento anual de 4,1 por 100. En ese aspecto acúdase al documento del organismo «Los pueblos indígenas en América Latina. Avances en el último decenio y retos pendientes para las garantías de sus derechos», noviembre de 2014, p. 7, disponible en bttps://repositorio. cepal.org/bitstream/handle/11362/37222/1/S1420521_es.pdf (consultado el 5 de diciembre de 2020).

${ }^{101}$ En ese orden, Bartolomé Clavero advierte que la DADPI «constituye una especificación de la Declaración de Naciones Unidas, siguiéndola en gran parte y reproduciéndola en forma literal o poco menos en ocasiones». Vid. B. Clavero, «La Declaración Americana sobre Derechos de los Pueblos Indígenas: el reto de la interpretación de una norma contradictoria», Lección impartida en el acto de recepción de la condecoración José León Barandarián de la Facultad de Derecho y Ciencias Políticas de la Universidad Nacional Mayor de San Marcos, Perú, 2016, p. 3, disponible en bttps://www.bartolomeclavero.net/wp-content/ uploads/2016/08/DADPI-Clavero.pdf (consultado el 18 de diciembre de 2020).

${ }_{102}$ No es ocioso recordar que la Asamblea General encargó a su Comisión de Asuntos Jurídicos y Políticos (órgano subsidiario del Consejo Permanente) la preparación de un «Proyecto de Declaración Americana sobre Derechos de las Poblaciones Indígenas», pensado para 1992, pero que emergió «veinticuatro años más tarde». Interesa señalar, a su vez, que en el año 1999 se dio el proceso de deliberación intergubernamental de las propuestas en relación con un instrumento regional bajo el título Declaración Americana sobre Derechos de las Poblaciones Indígenas, lo cual contrariaba lo dispuesto en el Convenio 169 de la OIT («pueblos»), siendo, por tanto, cambiada dicha acepción (poblaciones) por la de pueblos. Vid. B. Clavero, «La Declaración Americana sobre Derechos de los Pueblos Indígenas...», op. cit., pp. 1-2.

${ }^{103}$ N. YAÑEZ, «OEA: Declaración vulnera derechos de los pueblos indígenas», 2016, disponible en https://www.servindi.org/actualidad-opinion/23/06/2016/observanlimitaciones-en-declaracion-americana-sobre-derechos-de-los (consultado el 18 de diciembre de 2020). 
genas, como son la «libre determinación» (art. III) ${ }^{104}$ y la «autonomía» (art. XXII) ${ }^{105}$, ello lo hace, a diferencia de lo que acontece con el de la ONU (que trata «el derecho de autogobierno como forma de ejercicio de la libre determinación») ${ }^{106}$, de forma separada.

Otro de los cuestionamientos direccionados a la DADPI atañe a la noción «integracionista» de los derechos colectivos de los pueblos indígenas que la misma contempla, los cuales serán promovidos «por los Estados» (art. VI in fine $)^{107}$, «desperfilando la noción de pueblo y sus implicancias jurídicas para garantizar sus funciones autónomas» ${ }^{108}$.

En este contexto, también se vislumbran algunos inconvenientes en la redacción de la DADPI en lo tocante a las tierras, territorios y recursos de las comunidades indígenas, en virtud de que todos los aspectos (léase modalidades) que rodean a los mismos ( $v . g r$., propiedad, posesión, etc.) serán reconocidos «de acuerdo con el ordenamiento jurídico de cada Estado» (cfr. art. XXV.5), resultando, por tanto, «regresiva respecto de los estándares fijados por los órganos del Sistema Interamericano de Protección de Derechos Humanos, que reconocen el derecho de propiedad ancestral indígena en base a la ocupación» ${ }^{109}$.

De igual manera, y entre otras apelaciones al instrumento interamericano ${ }^{110}$, cabe destacar aquellas que explica Bartolomé Clavero, en particular

${ }^{104} \mathrm{El}$ mismo reza que los pueblos indígenas «tiene derecho a la libre determinación» y, en consecuencia, «determinan libremente su condición política y persiguen libremente su desarrollo económico, social y cultural».

${ }^{105}$ Se desprende de dicho artículo el derecho de los pueblos indígenas a «promover, desarrollar y mantener sus estructuras institucionales y sus propias costumbres, espiritualidad y tradiciones, procedimientos y prácticas».

${ }_{106}$ Es decir, en una lógica de la responsabilidad propia de los miembros de esas comunidades por las decisiones que adopten en sus asuntos y no a los Estados u organizaciones internacionales. Vid. B. Clavero, «La Declaración Americana sobre Derechos de los Pueblos Indígenas...», op. cit., pp. 3-4.

${ }_{107}$ Esta disposición normativa establece que los pueblos indígenas «tienen derechos colectivos indispensables para su existencia, bienestar y desarrollo integral como pueblos». Agrega, en esa línea, que los «Estados reconoce y respetan el derecho de los pueblos indígenas a su actuar colectivo; a sus sistemas o instituciones jurídicos, sociales, políticos y económicos; a sus propias culturas; a profesar y practicar sus creencias espirituales; a usar sus propias lenguas e idiomas, y a sus tierras, territorios y recursos». Ulteriormente señala que los Estados «promoverán, con la participación plena y efectiva de los pueblos indígenas, la coexistencia armónica de los derechos y sistemas de los grupos poblaciones y culturas».

${ }_{108}$ N. YAÑEZ, «OEA: Declaración vulnera derechos de los pueblos...», op. cit.

${ }_{109}$ Ibid.

${ }_{110}$ Así, por ejemplo, lo concerniente a la faz reparativa en supuestos de usurpación de patrimonio indígena, debido a que, conforme surge del art. XIII, inciso 2, la medida de «restitución» resulta facultativa («podrán») para los Estados, en tanto que la UNDRIP contempla que la definición de estos mecanismos de reparación se establezca conjuntamente con los pue- 
la vinculada al principio capital del consentimiento libre, previo e informado. Y es que advierte — reparando en los incisos 1 y 2 del art. XXIIIque el consentimiento es empleado de manera subsidiaria al derecho a la participación, por cuanto que en la UNDRIP, a contrario sensu, el consentimiento «es complementario ante todo al de autogobierno», es decir, que este principio es «independiente de carácter general como forma al cabo de ejercicio, junto al autogobierno, del derecho a la libre determinación» ${ }^{111}$.

\section{Aportes de la Corte Interamericana de Derechos Humanos}

A pesar de los cuestionamientos de los cuales deviene titular el instrumento interamericano, el sistema regional ha plasmado una dinámica en materia de pueblos indígenas. Tal aseveración se sustenta — como observaremos seguidamente- en diversos pronunciamientos de uno de sus principales órganos como es la Corte Interamericana de Derechos Humanos ${ }^{112}$ (en adelante, Corte IDH) ${ }^{113}$.

Con ese conocimiento es dable reparar, además, en el hecho de que la Corte IDH se encuentra facultada para interpretar no solo la normativa contemplada en el Pacto de San José y Carta de la OEA, sino que, además, puede entender en cualquier disposición en materia de derechos fundamentales, sea que provengan del sistema interamericano o del internacional de la ONU, no viéndose imposibilitada tampoco - $\mathrm{y}$ en caso de ser requerida consultivamente- para interpretar instru-

blos indígenas. En esa tesitura normativa tampoco se prevé, en lo que constituye el derecho «al desarrollo» de los pueblos, los beneficios de la explotación por parte de terceros en sus territorios, sino que da cuenta de la «restitución e indemnización como medida de mitigación frente a proyectos susceptibles de afectar la subsistencia de las sociedades indígenas» (cfr. art. XXIX, inc. 5). Vid. N. YAÑEZ, «OEA: Declaración vulnera derechos de los pueblos...», op. cit..

111 B. Clavero, «La Declaración Americana sobre Derechos de los Pueblos Indígenas...», op. cit., p. 5 .

112 Cabe recordar que la Corte IDH es una creación convencional con origen en el Pacto de San José de Costa Rica de 1969 - a diferencia de la Comisión Interamericana de Derechos Humanos, creada en 1959 en la «V Reunión Extraordinaria de Consultas de Ministros de Relaciones Exteriores» en Santiago de Chile-, cuya base normativa, en el Capítulo VIII (arts. 52 a 69), permite observar sus dos funciones primordiales como son la «consultiva» y la «contenciosa», que tienen por objeto «la aplicación e interpretación de la Convención Americana sobre Derechos Humanos» (cfr. art. 1 de su Estatuto). Ello, claro está, sin soslayar la función «cautelar» que ejercen tanto la Corte IDH (cfr. art. 63.2 CADH y 27 de su reglamento) como la Comisión IDH.

113 Asimismo, y a los fines de otorgar celeridad, se la aludirá como «Corte», «Tribunal» $\mathrm{u}$ «órgano jurisdiccional». 
mentos internacionales cuya naturaleza jurídica no sea estrictamente de derechos humanos.

Por consiguiente, sobre esa base vale decir que la labor de la Corte IDH ha encontrado, como basamento, distinta «normativa indígena», siendo sustancialmente el Convenio 169 de la OIT y la UNDRIP ${ }^{114}$, por lo que no correspondería circunscribir, a través de un solo instrumento — tal sería el caso de la DADPI—, su esfera de actuación en relación con la materia indígena.

\subsection{Algunos hitos jurisprudenciales en materia de propiedad comunal}

Es, pues, en la dirección argumental que esbozan las líneas del presente trabajo (derechos colectivos diferenciados) donde se abordarán algunos precedentes de la Corte IDH relativos a las tierras y territorios, dado el contexto actual que dota a la globalización de un protagonismo progresivo y, con ello, la constitución de un nuevo orden económico ( $v$. gr., empresas transnacionales intereses petroleros ${ }^{115}$, minería $\left.{ }^{116}\right)$ que, en muchos casos,

114 De ahí podría afirmarse que tanto el Convenio 169 como la UNDRIP se han convertido en instrumentos interamericanos sobre derechos de los pueblos indígenas «gracias a la labor jurisprudencial de la Corte Interamericana». Vid. B. Clavero, «La Declaración Americana sobre Derechos de los Pueblos Indígenas...», op. cit., p. 9.

115 En correspondencia con ello, René Unda Lara y María Fernanda Solórzano, haciendo hincapié en lo que acontece en la región Sierra Central (Ecuador) —relativo a la categoría «juventud indígena»-, explican que las mutaciones político-económicas que atravesó Ecuador (cuando se convierte en un país petrolero) conllevaron la «minifundización de la tierra con la consecuente precarización de las condiciones de producción para los pequeños productores, es decir, para la mayor parte de la población indígena», contexto este que, por tanto, aparejó «la búsqueda de mejores condiciones de vida en los procesos migratorios del campo a la ciudad» («rurbanización»). Vid. R. Unda LARA y M. F. SOLÓRZANO, «Jóvenes indígenas en la Sierra Central de Ecuador. Elementos para pensar sus prácticas comunitarias», Desidades, núm. 4 (2014), pp. 15-16, disponible en https://www.researchgate.net/profile/ Rene_Unda_Lara/publication/317458120_Jovens_indigenas_na_Sierra_Central_do_Equador_ Elementos_para_pensar_suas_praticas_comunitarias/links/59f8a46e0f7e9b553ec0bad1/Jovensindigenas-na-Sierra-Central-do-Equador-Elementos-para-pensar-suas-praticas-comunitarias.pdf (consultado el 4 de diciembre de 2020). Cabe recordar, en ese sentido, el precedente Pueblo indígena Kichwa de Sarayaku, al que nos referiremos en las presentes líneas.

116 Esto es de observar en el suroeste de la ciudad de Puerto Maldonado (sureste de la Amazona, lado de Perú), en particular en el periodo de 1999 a 2003, donde la deforestación, a raíz de la minería aurífera fluvial de oro desplegada de manera legal o ilegal entre sus motivos principales (otros se inclinan a la agricultura migratoria y la tala ilegal)alcanzó las 55.426 hectáreas. Vid. G. Alarcón, J. Díaz, M. Vela, M. García y J. GutiéRREZ, «Deforestación en el sureste de la Amazonia del Perú entre los años 1999-2003: caso Región de Madre de Dios (Puerto Maldonado-Inambari)», Revista de Investigaciones 
conlleva la conformación de asentamientos indígenas urbanos y metropolitanos, así como de comunidades transfronterizadas.

En efecto, atendiendo a la emergencia sanitaria actual derivada de la pandemia del Covid-19, cabe puntualizar algunos acontecimientos de los últimos tiempos.

Y es que las consecuencias de las mentadas actividades (empresariales) han sido sufridas - como en su momento por la comunidad tribal Saramaka (a la que se menciona en el presente trabajo)_ por miembros de la comunidad indígena Mura del Amazonas (Brasil), quienes, principalmente por el contexto pandémico - el cual contribuyó en «el aumento de los precios del oro y la retirada de las fuerzas militares y policiales»-, han visto (entre otras comunidades) conculcados sus derechos colectivos (tierras y territorios) por la expansión de operaciones mineras ilegales ${ }^{117}$.

$\mathrm{Al}$ respecto colegimos que este escenario contradice de forma palmaria lo dispuesto por la Corte IDH en el apartado cuarto de su declaración «Covid-19 y derechos humanos: los problemas y desafíos deben ser abordados con perspectiva de derechos humanos y respetando las obligaciones internacionales», de 9 de abril de 2020, en cuanto refiere el deber de garantizar, por parte de los Estados, los derechos económicos, sociales, culturales y ambientales (DESCA) a toda persona bajo su jurisdicción, en particular «aquellos grupos que son afectados de forma desproporcionada porque se encuentran en una situación de mayor vulnerabilidad», entre los que se encuentran las comunidades indígenas ${ }^{118}$.

A tenor de lo mencionado debe ser sopesado también el inciso 57 de la Resolución 1/20, «Pandemias y derechos humanos en las Américas», adoptada por la Comisión IDH el 10 de abril de 2020, el cual da cuenta del deber de «abstención» a promover iniciativas legislativas con fines «productivos y/o extractivos en los territorios de los pueblos indígenas» en el transcurso de la situación pandémica, en vista de la imposibilidad — por las medidas de distanciamiento social- de «llevar adelante los procesos de consulta previa, libre e informada» ${ }^{119}$.

Altoandinas, núm. 3 (2016), pp. 319-330 disponible en https://dialnet.unirioja.es/servlet/ articulo? codigo $=5645610$ (consultado el 5 de diciembre de 2020).

117 Vid. bttps://www.infobae.com/americalagencias/2020/10/07/la-mineria-del-amazonas-ocupa-20-de-las-tierras-indigenas-y-empeora-la-deforestacion-informe-2/ (consultado el 5 de diciembre de 2020).

118 Vid. https://www.corteidh.or.cr/tablas/alerta/comunicado/declaracion_1_20_ESP.pdf (consultado el 5 de diciembre de 2020).

${ }_{119}$ Vid. http://www.oas.org/es/cidh/decisiones/pdf/Resolucion-1-20-es.pdf (consultado el 5 de diciembre de 2020). 
En ese sentido se podría aseverar que muchas veces la «promoción» enarbolada por el Banco Mundial (una de las organizaciones multinacionales con más gravitación en lo que atañe a la asistencia económica de los países) —en cuanto a la «diversidad cultural» se refiere— se sostiene, en su línea discursiva, siempre que la misma no sea «disfuncional» a las actividades de tinte económico ( $v . g r$., petroleras, de explotación, etc. $)^{120}$.

Pues bien, en atención a lo expuesto y con miras a diferenciar la noción privatista de la propiedad que prima en las sociedades de la que importa para las poblaciones indígenas (sui generis), es menester señalar que el concepto de territorio no se circunscribe a una sola concepción, sino, por el contrario, y en línea con la postura del historiador chileno Víctor Toledo Llancaqueo, la misma trae aparejada varias acepciones, ya sea como «jurisdicción de control político» (vinculado a los aspectos legales y administrativos involucrados con el ejercicio de autogobierno), como «espacios geográficos» (no solo como parcelas, sino también, y en especial, como puntos de reproducción de las comunidades), como «hábitats» ${ }^{121}$ (en estrecha relación con los recursos naturales que yacen sobre los territorios) ${ }^{122} \mathrm{o}$ como «biodiversidad y conocimientos» y «simbólicos e históricos» (el mismo guarda correspondencia con la etno-territorialidad $\left.{ }^{123}\right)^{124}$.

${ }^{120} \mathrm{Vid}$., en caso de interés del/la lector/a, el trabajo del doctor argentino E. DOMENECH, «El Banco Mundial en el país de la desigualdad: políticas y discursos neoliberales sobre diversidad cultural y educación en América Latina», en Cultura y Neoliberalismo, Buenos Aires, CLACSO, 2007, p. 72, disponible en https://www.aacademica.org/eduardo.domenech/35 (consultado el 4 de diciembre de 2020).

${ }^{121}$ En este aspecto, y en sintonía con el catedrático venezolano Ricardo Colmenares Olivar, cabe destacar que la «autonomía indígena» se encuentra inescindiblemente en relación con el «hábitat», pues «no se puede ejercer control y autoridad (jurisdicción) si no existe plenamente demarcada un área o espacio natural donde aplicarlo (competencia)». Vid., en ese orden, R. Colmenares Olivar, «El derecho a la autonomía de los pueblos indígenas en Venezuela», Revista del Centro de Investigaciones Penales Criminológicas Héctor Febres Cordero (CENIPEC), núm. 21 (2002), p. 196, disponible en https://www.guao.org/sites/default/ files/biblioteca/Dercho\%20Autonomia\%20PI.pdf (consultado el 26 de noviembre de 2020).

${ }_{122} \mathrm{Tal}$ como se desprende del Convenio 169 de la OIT.

${ }^{123}$ A propósito de ello, Alicia Barabas advierte — analizando el caso de las comunidades originarias de Oaxaca (México) — que los «etnoterritorios» son aquellos «espacios poseídos por poderosas entidades anímicas territoriales llamadas dueños, señores, padres o reyes de lugares: dueño del cerro o del monte, de la tierra, de los animales, del agua, del viento, del rayo». En otras palabras, «cada lugar "pertenece" a una entidad anímica territorial potente ante la cual las personas deben realizar rituales, ofrendas y sacrificios» para que las mismas no sean ofendidas. Acúdase, a tales fines, a su artículo A. BARABAS, «Cosmovisiones y etnoterritorialidad en las culturas indígenas de Oaxaca», Antipoda: Revista de Antropología y Arqueología, núm. 7 (2008), disponible en http://www.scielo.org.co/scielo.php?script=sci_arttextEpid $=$ S1900-54072008000200007 (consultado el 4 de diciembre de 2020).

${ }^{124}$ V. LlancaqueO, «Políticas indígenas y derechos territoriales en América Latina, 
En consecuencia, habida cuenta de estas consideraciones, es dable reparar en algunos hitos de la Corte IDH que con el transcurso del tiempo han ido delineado los parámetros a considerar al momento de analizar los derechos colectivos de los pueblos indígenas, en especial los relativos a sus tierras y territorios.

En ese sentido cabe recordar el caso Comunidad Mayagna (Sumo) Awas Tigni c. Nicaragua ${ }^{125}$, del 31 de agosto de 2001. En dicha oportunidad y en lo que aquí respecta, el Tribunal puso de relieve que la disposición normativa del art. 21 de la Convención Americana sobre Derechos Humanos (en adelante, CADH o Pacto de San José de Costa Rica), referente al derecho de propiedad privada, en sintonía con la previsión del art. 29.b) de dicho cuerpo normativo, no debía ser interpretada como «excluyente» de la propiedad comunal que les corresponde a las comunidades indígena (apdo. 148). En tal entendimiento, se dijo que la propiedad comunal presenta características propias, siendo que «la pertenencia a esta no se centra en un individuo, sino en el grupo y en la comunidad», a quienes les asiste el derecho de plena libertad de vivir en sus territorios (apdo. 149). Es, pues, en este contexto en el que debe de ser comprendida la «estrecha relación que los indígenas mantienen con la tierra», entendida esta como «la base fundamental de sus culturas, su vida espiritual, su integridad y su supervivencia económica» y no como una mera «cuestión de posesión y producción» (apdo. 149). En vista de ello, el órgano jurisdiccional advirtió que, en lo que hace a las comunidades originarias y sus territorios, rige un «derecho consuetudinario» y que, por tanto, se debe prescindir de las formalidades que orbitan en la esfera civilista de la propiedad, es decir, que, no obstante no tener un título real sobre la propiedad, en el caso de las comunidades basta con la «posesión de la tierra» ${ }^{126}(\text { apdo. } 151)^{127}$.

1900-2004. ¿Las fronteras indígenas de la globalización?», en P. DÁvalos (coord.), Pueblos indígenas, estado y democracia, Buenos Aires, CLACSO, 2005, pp. 88-95, disponible en https://core.ac.uk/download/pdf/35174747.pdf (consultado el 26 de noviembre de 2020).

${ }^{125}$ Del racconto de los hechos se desprende que la comunidad Awas Tingni — conformada por más de 600 personas - celebró un contrato con la empresa MADENSA a los fines de determinar el manejo integral del bosque. Sin embargo, y a pesar del acuerdo que concretó la comunidad con la empresa y el Ministerio de Ambiente y Recursos Naturales de Nicaragua (MARENA) para facilitar la definición de las tierras comunales de la comunidad, en 1996 el Estado otorgó, sin consulta previa al pueblo Awas Tingni, una concesión por el lapso de treinta años para el manejo y aprovechamiento forestal de 62.000 hectáreas a la empresa SOLCARSA.

126 Estos postulados jurisprudenciales se plasmaron también en la causa Comunidad Moiwana vs. Suriname, de 15 de junio de 2005, donde se infieren - entre otros puntosla intrínseca relación entre la comunidad —en este caso el pueblo tribal de N'djuka (com- 
Esta sentencia reviste una importancia mayúscula, dado que, como advierte el entonces magistrado brasileño Antônio Augusto Cancado Trindade — quien destaca la «dimensión intertemporal» ${ }^{128}$ de la comunidad indígena con sus tierras (apdo. 8 de su voto razonado)—, se profundiza, por primera vez, «en una interpretación integral de la cosmovisión indígena como punto central» (apdo. 13 de su voto razonado).

Posteriormente, y en la misma sintonía, la Corte IDH se pronunció en la sentencia Comunidad indígena Yakye Axa c. Paraguay ${ }^{129}$ de 17 de junio de 2005, determinando —entre sus ponderaciones más relevantes- que se habían afectado los derechos y garantías procesales que hacen al debido proceso adjetivo. Y es que, a ese respecto, el proceso ${ }^{130}$ de reivindicación de tierras (que debe ser atendido respecto de sus particularidades) no respetó, por letargo estatal, el plazo razonable (apdo. 98), lo cual contraría las disposiciones 8 y 25 del Pacto de San José de Costa Rica, máxi-

puesto por personas originarias de África) - y sus tierras («relación onmicomprensiva»), cuyos límites «solo pueden determinarse previa consulta con dichas comunidades vecinas» (apdos. 131 y 133). Vid. https://www.corteidh.or.cr/docs/casos/articulos/seriec_124_esp1.pdf (consultado el 5 de diciembre de 2020).

127 Vid. https://www.corteidh.or.cr/docs/casos/articulos/Seriec_79_esp.pdf (consultado el 27 de noviembre de 2020).

${ }^{128}$ Esto es, derechos que tiene los pueblos indígenas a «practicar, conservar y revitalizar sus costumbres culturales», preservando, de este modo, sus tradiciones pasadas para poder desarrollarlas con las generaciones futuras. Léase lo mencionado en consonancia con el art. 13.1 UNDRIP.

${ }^{129}$ De la plataforma fáctica surge que la comunidad actora — conformada por más de trescientas personas - se debió trasladar en el año 1986 — con motivo de las condiciones de vida en las estancias ganaderas donde laboraban y que se habían construido ante la llegada de empresas británicas y grupos misioneros de la iglesia anglicana- a otras extensiones de tierras. A pesar de esto, su situación se agravó, lo que provocó que en el año 1993 iniciaran el correspondiente procedimiento administrativo para reivindicar sus tierras.

${ }_{130}$ En ese tenor, y más allá de la denominación como «procesos» — tanto para referirse a la instancia jurisdiccional como administrativa-, cabe recordar algunos preceptos relativos a la «faz judicial» y a la «faz administrativa» en los que ya, en su oportunidad y para el ámbito interno del Estado argentino, reparaba el administrativista argentino Armando Emilio Grau. En ese orden, consideraba que, no obstante ambas nociones (instancia judicial y administrativa) suelen tener puntos de conexión ( $v$. gr., indican la presencia de una actividad jurídica), se diferencian desde un punto de vista «orgánico» (el órgano que realiza la función pública en el proceso es judicial y el del procedimiento es administrativo), «objetivo» (la función que se ejercita en el proceso es judicial y la que se realiza en el procedimiento es administrativa) y, por último, «finalista» (el fin del proceso es el dictado de una sentencia para decidir una causa; el procedimiento puede tener diversos fines: decidir una cuestión, determinar una situación, seleccionar el destinatario de un acto o una persona contratante, etc.). Acúdase, en caso de interés, a A. E. GRAU, Habilitación de la instancia contencioso-administrativa, La Plata, Editora Platense, 1971, pp. 20-21 (consultado el 5 de diciembre de 2020). 
me cuando al respecto se deben de ponderar «las características propias que diferencian a los miembros de los pueblos indígenas de la población en general y que conforman su identidad cultural» (cfr. apdo. 51). A su vez, y entre los puntos medulares referentes a la propiedad comunal bajo la óptica de los arts. 21 y 29 CADH (apdos. $131^{131}, 132^{132}$, etc.), reparó en la interrelación que guarda el derecho a las tierras en relación con los derechos sustanciales, como el de «la identidad cultural y la supervivencia misma de las comunidades indígenas y sus miembros» (apdo. 147). Sin embargo, este precedente fue un punto de inflexión en la materia, en tanto que estableció el «derecho de las comunidades originarias a recuperar sus tierras» (apdos. 210 a 215).

Nuevamente, en el año 2006 llegaría a los estrados del Tribunal un caso que tendría al Estado de Paraguay como demandado. Así se vislumbró en la causa del 29 de marzo de 2006, Comunidad Indígena Sawboyamaxa c. Paraguay ${ }^{133}$, donde la Corte IDH se referiría a precedentes - como los ya aludidos- en los que se habían sentado principios fundantes en materia indígena; ello a la luz de los arts. 21 y 29 CADH y el Convenio 169 de la OIT. Sin embargo, podemos observar algunas notas características del sub judice, tal como se refleja en la cuestión de la «posesión de tierras». Al respecto, el órgano jurisdiccional puso de relieve que la posesión tradicional «tiene efectos equivalentes al título de pleno dominio» que les otorga a los pueblos indígenas «el derecho de exigir el reconocimiento oficial de su propiedad y su registro»; derecho este que, inclusive en el supuesto de que algunos de sus miembros hayan perdido involuntariamente la posesión sobre las mismas, se mantendrá incólume pese a haber sido trasferidas a un tercero de buena fe, en cuyo caso los miembros de la comunidad tendrán «el derecho a recuperarlas o a obtener otras tierras

${ }_{131}$ Concerniente a la inescindible relación que existe entre las comunidades originarias con sus tierras, siendo aquella «la base fundamental de su cultura, vida espiritual, integridad, supervivencia económica y su preservación y transmisión a las generaciones futuras».

132 Destacan las particularidades de los pueblos indígenas por su «forma de vida particular de ser, ver y actuar en el mundo» y que, a pesar de los recursos necesarios para su subsistencia, sus tierras forman parte integrante de su «cosmovisión, religiosidad y, por ende, de su identidad cultural».

${ }^{133}$ Los hechos del caso se originan a raíz de la individualización de las tierras pertenecientes a la comunidad Sawhoyamaxa en el Chaco paraguayo a dos empresas privadas. A partir de tal circunstancia, los miembros de la comunidad comenzaron a erigir sus reclamos (faz reivindicatoria) que, a pesar de varios intentos (proyecto de ley al presidente de la Cámara de Diputados del Congreso de la Nación con miras a que se declare de interés social dichas tierras y, por consiguiente, las mismas sean expropiadas, así como también la consecuente presentación de recursos judiciales), no tuvieron éxito. 
de igual extensión y calidad» ${ }^{134}$ (vid., apdos. 128 y 131). Otro de los puntos que, colegimos, conllevan una trascendencia mayúscula es en relación con la determinación del momento en que ese derecho colectivo (tierras) caduca. Al respecto, el Tribunal considera que el derecho sobre las tierras (léase derecho de reivindicación) de los que devengan titulares los pueblos indígenas se conservará hasta el momento en que subsista entre aquellos y la tierra el sustrato «espiritual y material de la identidad de los pueblos indígenas» (apdo. 131) $)^{135}$.

Ya el 28 de noviembre de 2007, el órgano jurisdiccional lo analizaría en los autos Pueblos Saramaka c. Surinam ${ }^{136}$. Allí, y más allá de las consideraciones en similar sentido $\left(v \cdot g r\right.$., apdo. $90^{137}$, etc.) que se mencionaron con antelación, el Tribunal adujo que el Estado tenía una «obligación positiva de adoptar medidas especiales» para garantizar el «ejercicio pleno e iguali-

${ }^{134}$ En esa tesitura se expresó el Tribunal en el caso Comunidad Indígena Xákkmok Kásek c. Paraguay, de 24 de agosto de 2010 (vid. apdos. 109, 110, 111 y 116). En dicho caso se consideró la relación especial de los miembros del pueblo con sus tierras (apdos. 174, 175, 176 y 177, entre otros) y que, en la situación actual en la que se encontraban aquellos — por lo cual se les ofrecieron tierras alternativas que «no cumplían los requisitos necesarios» (apdo. 119)—, se veían imposibilitados de hablar «sus propias lenguas» (cfr. apdo. 179), consecuencia de la venta del Estado a propietarios privados de dos tercios de terrenos ubicados en la región del Chaco paraguayo. Vid. https://www.corteidh.or.cr/docs/ casos/articulos/seriec_214_esp.pdf (consultado el 6 de diciembre de 2020).

135 Vid. https://www.corteidh.or.cr/docs/casos/articulos/seriec_146_esp2.pdf (consultado el 5 de diciembre de 2020).

${ }^{136}$ En lo que respecta a los hechos del presente caso, la comunidad tribal Saramaka —con características culturales específicas y una red de relaciones complejas con la tierra y las estructuras familiares - no contaba con un territorio propio, dado que el suyo se encontraba ocupado desde comienzos del siglo XVIII. Sin embargo, en su momento se le había reconocido — por las autoridades estatales - un grado de autonomía para que dispusiera de aquel (territorio), lo cual no obstaculizó a que el Estado otorgara —en un sentido contradictorio con su actuar (non venire contra factum propium o teoría de los actos propios) - concesiones a empresas madereras y de minería, generando así un daño irreversible a los territorios de la comunidad (medio ambiente) que, pese a los reclamos del pueblo, no cesó en vista de la inacción — con fundamentos eufemísticos- del Estado.

137 El mismo se direcciona, con base en precedentes del órgano jurisdiccional, a resguardar, a tutelar por la «relación especial» de los pueblos indígenas y tribales con sus territorios, necesarios, a su vez, para su «supervivencia física y cultural». Esta premisa fundamental la reiteraría en casos como Pueblo indígena Xucuru y sus miembros vs. Brasil, de 5 de febrero de 2018 (vid. apdos. 115, 116, 117, 118, 121, 127 y 128, in fine), entre otros. De igual manera, en dicho pronunciamiento y en vista del principio de «seguridad jurídica», la Corte IDH —al igual que lo hizo en el precedente Kaliña y Lokono (apdo. 133) — puso de relieve la necesidad de «materializar los derechos territoriales de los pueblos indígenas a través de la adopción de medidas legislativas y administrativas» que resultan esenciales «para crear un mecanismo efectivo de delimitación, demarcación y titulación» (cfr. apdo. 119), Vid. https://www.corteidh.or.cr/docs/casos/articulos/seriec_346_esp.pdf (consultado el 8 de diciembre de 2020). 
tario del derecho» respecto de sus territorios (apdo. 91). De igual manera, no se debe soslayar el hecho de que la Corte, pese a que el Estado - el cual no contempla en su legislación interna el derecho a la propiedad comunal- no había ratificado el Convenio 169 de la OIT, sustentó su decisión en los arts. 21 y $29 \mathrm{CADH}$ y «a la luz de los derechos reconocidos en los arts. 1 en común y 27 del PIDCP» (apdo. 95) ${ }^{138}$.

No es ocioso recordar que el 12 de agosto de 2008, con motivo de dicha resolución, la Corte IDH determinaría el deber del Estado de Surinam a efectuar las consultas correspondientes a la comunidad Saramaka en lo tocante a «la delimitación, demarcación y otorgamiento de título colectivo» de su territorio; «el reconocimiento legal de la capacidad jurídica colectiva»; «la adopción de medidas legislativas, administrativas o de otra índole» que sean necesarias para garantizar el derecho colectivo a sus territorios y para que la consulta sea adecuada a las costumbres de la comunidad originaria; «sobre los resultados» del impacto social y ambiental, y, sustancialmente, «en relación con cualquier restricción a los derechos de propiedad del pueblo Saramaka» que supongan proyectos de desarrollo o de inversión (apdo. 16), siendo, además, imperioso contar con el «consentimiento libre, previo e informado para la protección de los derechos humanos de los pueblos indígenas» ${ }^{139}$ (apdo. 135) ${ }^{140}$.

En consonancia con el panorama expuesto, la Corte, en el caso Kichwa de Sarayaku c. Ecuador ${ }^{141}$ de 27 de junio de 2012, reputaría —en relación con la propiedad comunal- el «derecho a la consulta» ${ }^{142}$. Precisamente, la

${ }_{138} \mathrm{Vid}$. https://www.corteidh.or.cr/docs/casos/articulos/seriec_172_esp.pdf (consultado el 6 de diciembre de 2020).

139 Precisamente en supuestos en los que, como consecuencia de «proyectos de gran escala», las comunidades originarias deban atravesar «cambios sociales y económicos profundos» ( $v$. gr., traslados, migración, agotamiento de recursos necesarios para la subsistencia física y cultural, la destrucción y contaminación del ambiente, la desorganización social y comunitaria, entre otras).

${ }_{140}$ Vid. https://www.corteidh.or.cr/docs/casos/articulos/seriec_185_esp.pdf (consultado el 6 de diciembre de 2020).

${ }^{141}$ Conforme se deduce de la plataforma fáctica del caso, se infiere —en sus puntos centrales- que la comunidad Kichwa vio conculcados, por el avasallamiento de empresas petroleras que ingresaron a sus territorios, sus derechos colectivos $(v \cdot g r$., destrucción de cuevas y fuentes de agua, así como también la tala de árboles y plantas) y, consiguientemente, sus derechos más fundamentales para su subsistencia ( $v$. gr., alimentación, agua), no habiendo sido la comunidad, en ningún momento, notificada de los acuerdos (léase términos de la negociación) celebrados entre el Estado y las empresas petroleras.

${ }_{142}$ Se podría edificar, en lo que al caso concierne y en la línea de pensamiento de la ya citada Raquel Yrigoyen Fajardo, una crítica en torno a la evocación, por parte del órgano jurisdiccional, del «derecho de consulta», mas no al del «consentimiento». Y es que este último (consentimiento) es necesario para supuestos donde corra un grave desequilibro 
importancia capital de la causa radica en delinear los parámetros de aquel derecho (consulta). Así, y en primer lugar, determinó el carácter «previo» que debe revestir toda consulta ${ }^{143}$, es decir, que, tomando en consideración lo dispuesto en el Convenio 169 de la OIT, la consulta debe realizarse «en las primeras etapas del plan de desarrollo o de inversión y no únicamente cuando surja la necesidad de obtener la aprobación de la comunidad», en tanto que el no efectuarlo de este modo conllevaría conflictividades — como aconteció en el sub lite - entre las comunidades (apdo. 180). Se sigue de ello, además, la «buena fe» ${ }^{144}$ que debe primar en las consultas a los fines de llegar a un acuerdo, en virtud de la cual estas últimas deben plasmar la verdadera participación de las comunidades - a través del diálogo entre las partes basado en el respeto mutuo- y no el cumplimiento de un «mero trámite formal» (apdo. 186). Asimismo, la Corte puso de relieve que la obligación de consultar «es una obligación del Estado» de la cual no puede eximirse, siendo que es un deber público que no puede ser delegado a empresas privadas o a terceros (apdo. 187). Siendo así, el Tribunal también tuvo dicho que todos aquellos procedimientos que conlleve la consulta deben ser «culturalmente adecuados», esto es, de «conformidad con sus propias tradiciones» ${ }^{145}$ (apdo. 201), puesto que, de lo contra-

— tal es el caso- la organización de la comunidad (apélese a los apdos. 131, 134 y 135 de la Corte IDH en la causa Saramaka). Ciertamente, para estos supuestos resulta imprescindible contar con el consentimiento - como requisito- de los pueblos indígenas. En otras palabras, el Estado debe contar con dicho consentimiento «para que tome una decisión», siendo, por tanto, el consentimiento previo, libre e informado «un derecho reforzado de carácter específico, que constituye un requisito adicional al ejercicio de otros derechos (como la participación o la consulta previa) para que el Estado pueda tomar una decisión, cuando la materia en cuestión está referida a hechos que puedan afectar derechos fundamentales de los pueblos indígenas y poner en riesgo su integridad». Vid. R. YRIGOYEn FajARDO, «De la tutela indígena a la libre determinación del desarrollo, la participación, la consulta y el consentimiento», en L. G. UsCáteguI GÓMEZ (ed.), El derecho a la consulta previa en América Latina. Del reconocimiento formal a la exigibilidad de los derechos de los pueblos indígenas, Bogotá, Instituto Latinoamericano de Servicios Legales Alternativo, 2009, p. 30, disponible en http://www.ilsa.org.co/biblioteca/ElOtroDerecho/Elotroderecho_40/El_otro_derecho_40. pdf\#page=11 (consultado el 28 de noviembre de 2020).

${ }^{143}$ La misma comprende también la adopción de todas aquellas medidas legislativas, entre otras (cfr. apdo. 181).

${ }^{144}$ En esa sintonía, la Corte coligió que las consultas deben ser «informadas», por cuanto en dichos procedimientos en los que resulte destinataria la comunidad se deben pronosticar «los posibles riesgos del plan de desarrollo o inversión propuesto, incluidos los riesgos ambientales y de salubridad» (apdo. 208).

${ }_{145}$ En ese sentido, el órgano, advirtiendo los aportes de expertos en la materia, advirtió que los «procedimientos apropiados» no deben estandarizarse, sino, por el contrario, y dada la heterogeneidad que rodea a las comunidades indígenas, se deben «tener en cuenta las circunstancias nacionales» y la de los pueblos indígenas (apdo. 202). 
rio, se estaría conculcando - por su indisoluble relación con los derechos a la consulta y a la propiedad comunal - el derecho a la identidad cultural ${ }^{146}$ (tradiciones, costumbres, lenguas, artes, rituales ${ }^{147} \mathrm{y}$ conocimientos, entre otros aspectos fundamentales de las comunidades indígenas) ${ }^{148}$.

Asimismo, el Tribunal, en el caso Pueblos Indígenas Kuna de Madungandí y Emberá de Bayano y sus miembros c. Panamá ${ }^{149}$ de 14 de octubre de 2014, sopesó - entre algunas de las premisas fundamentales sobre la materia en las que ya había reparado ( $v i d$. apdos. 111, 112 y 117 , entre otros) ${ }^{150}$ y a los fines de su validez- la materialización de lo jurídicamente establecido en lo que a derechos colectivos indígenas atañe, es decir, que «el reconocimiento meramente abstracto o jurídico de las tierras, territorios o recursos

146 Este debe ser concebido como «un derecho fundamental y de naturaleza colectiva» (apdo. 217).

${ }^{147}$ En el presente caso, en virtud del accionar de las empresas petroleras, el pueblo Sarayaku tuvo que suspender, en un territorio estéril — por la destrucción de árboles sagrados, montañas y la consecuente inmigración de los espíritus del lugar-, la Uyantsa, festividad más importante que celebran de manera anual (apdo. 218).

148 Vid. https://corteidh.or.cr/docs/casos/articulos/seriec_245_esp.pdf (consultado el 6 de diciembre de 2020).

${ }^{149}$ En lo que respecta al caso, el mismo se origina a raíz de la prosecución, en el año 1972, de obras hidroeléctricas para construir una represa en la zona del Alto Bayano (Provincia de Panamá). En efecto, en vista de tal panorama (inundaciones) se vieron afectadas reservas indígenas, por lo que el Estado otorgó nuevas tierras en zonas adyacentes a las ya afectadas. Así las cosas, y a pesar de la concertación de cuatro acuerdos —atinentes a cuestiones indemnizatorias y de reubicación - entre el Estado y los representantes de las comunidades perjudicadas, dichas circunstancias se agudizarían en el año 1990, más aún frente a la conflictividad ( $v$. gr., por daño ecológico y delitos contra el ambiente) que suponía la coexistencia entre los pueblos y los campesinos no indígenas (colonos), todo lo cual conllevó al inicio, por miembros de las comunidades originarias, distintas peticiones en la instancia jurisdiccional y administrativa.

${ }^{150}$ A saber, la pertenencia de los territorios centrada «en la comunidad» y no en sus miembros; conexión esta que, manteniéndose intacta con la posesión tradicional —con «efectos equivalentes al título de pleno domino»-, resulta esencial para «su supervivencia física y cultural». Ello sin obviar la obligación de aquellos Estados pertenecientes a la Organización de Estados Americanos (OEA) que han aceptado la competencia contenciosa de la Corte IDH — entre los que se halla Argentina - de «delimitar, marcar y titular las tierras de los pueblos indígenas» (apdo. 118); postura, esta última, que ha sostenido en causas como Garifuna de Punta de Piedra y sus miembros vs. Honduras, de 8 de octubre de 2015 (acúdase al apdo. 107, así como a los apdos. 216, 218 y 224 en los que se determinó, con base en el precedente Kichwa de Sarayaku, que no se había efectuado «un proceso adecuado y efectivo que garantizara el derecho a la consulta»). Vid. https://www.corteidh.or.cr/docs/casos/articulos/seriec_304_esp.pdf (consultado el 7 de diciembre de 2020). Apélese, en idéntico sentido, a los apartados 158, 159, 160 y 182 de la Sentencia Garífuna Triunfo de la Cruz y sus miembros vs. Honduras, de 8 de octubre de 2015, disponible en https://www.corteidh.or.cr/docs/casos/articulos/seriec_305_esp.pdf (consultado el 7 de diciembre de 2020). 
indígenas carece prácticamente de sentido si no se ha establecido y delimitado físicamente la propiedad» (apdo. 135). En esa sintonía, y como acontece con los derechos humanos en su plano individual, atendió al carácter «inalienable e imprescriptible» de los territorios indígenas (apdo. 142), que, dada su «situación de especial vulnerabilidad, su derecho consuetudinario, sus valores, usos y costumbres» (apdo. 167), deben ser protegidos — desde una faz positiva y negativa (apdo. 192) — ${ }^{151}$ por el Estado ${ }^{152}$.

Interesa señalar que la Corte IDH, en la causa Pueblos Kaliña y Lokono c. Surinam ${ }^{153}$ de 25 de noviembre de 2015, marcaría un punto de inflexión (léase evolución interpretativa) en la materia. Y es que el Tribunal, por primera vez y con sustento en el principio iura novit curia (apdo. 126), basó el derecho a la consulta ${ }^{154}$ en el art. $23 \mathrm{CADH}^{155}$, esto es, en los denominados «derechos políticos» ${ }^{156}$ que el decálogo contempla en razón del interés que afecta —que trasunta el público- a los miem-

151 En otras palabras, no solo se deben salvaguardar los derechos colectivos de las comunidades originarias con la adopción de medidas legislativas, sino, a su vez, evitando promulgar normativa que obstaculice el ejercicio pleno de tales derechos.

152 Vid. https://www.corteidh.or.cr/docs/casos/articulos/seriec_284_esp.pdf (consultado el 6 de diciembre de 2020).

153 Respecto a los acontecimientos que motivan la resolución del Tribunal, los mismos se dan en el marco de una conjunción de conflictos relativos a los territorios de las distintas aldeas (ocho en total) que componen las comunidades de Kaliña y Lokono, y que limitan con los de la tribu N'djuka maroon, siendo que en dichos territorios se crearon tres reservas naturales que, sin embargo, se vieron afectadas por diversas disposiciones estatales $(v . g r$., presencia militar, actividades de minería). A ello cabe añadir que las autoridades públicas otorgaron títulos a terceros no indígenas en áreas contiguas a las viviendas de los miembros de las comunidades indígenas.

154 En lo que respecta al «derecho al territorio colectivo» (apdo. 125). Asimismo, dispuso que «la falta de delimitación, demarcación y titulación» de los territorios indígenas supone sustancialmente la conculcación al derecho «a la propiedad colectiva» (cfr. apdo. 142).

${ }^{155}$ A propósito de ello cabe recordar —en lo que hace a la esfera de derechos políticos que orbita en las comunidades indígenas- el caso Yatama c. Nicaragua, de 23 de junio de 2005, en cuya ocasión el órgano jurisdiccional dispuso que se habían socavado —en sintonía con los arts. 1.1 («obligación de respetar los derechos»), 2 («deber de adoptar disposiciones de Derecho interno»), 8.1 («garantías judiciales»), 24 («igualdad ante la Ley») y 25.1 («protección judicial») del Pacto de San José de Costa Rica- los derechos políticos de los miembros de la comunidad indígena Yapti Tasba Masraka Nanih Asla Takanka (YATAMA), quienes intentaron obtener la autorización para ser reconocidos como partido político regional (vid., en ese sentido, los apdos. 164, 169, 176, 186, 194, 217 y 229, entre otros) Vid. https:// www.corteidh.or.cr/docs/casos/articulos/seriec_127_esp.pdf (consultado el 13 de diciembre de 2020).

${ }_{156}$ Entre los que se establecen el derecho a «participar en la dirección de los asuntos públicos», «votar y ser elegidos en elecciones periódicas» y a tener «acceso, en condiciones generales de igualdad, a las funciones públicas». 
bros de los pueblos indígenas por los derechos que se encuentran comprometidos (apdo. 196) ${ }^{157}$.

Actualmente, la Corte ha ido precisando aún más aquellos aspectos que afectan a los derechos colectivos diferenciados de los pueblos indígenas. Así se observa en pronunciamientos como el caso Comunidades indígenas Miembros de la Asociación Lhaka Honhat (Nuestra Tierra) c. Argentina $^{158}$ de 6 de febrero de 2020, en cuya ocasión el Tribunal, haciendo un racconto de su doctrina en la materia, advirtió nuevamente la relación existente entre la propiedad comunal de los pueblos indígenas y los «derechos políticos» ${ }^{159}$ que prevé el art. $23 \mathrm{CADH}$ (apdo. 173). A su vez determinó, sobre la base de las diferencias que existen entre el «mantenimiento o mejora de obras ya existentes» y la «realización de obras o proyectos nuevos», que en el primer supuesto (obras ya existentes) no siempre el mismo conlleva el deber estatal de la consulta previa. Y es que ello «podría impli-

157 Vid. https://www.corteidh.or.cr/docs/casos/articulos/seriec_309_esp.pdf (consultado el 7 de diciembre de 2020).

${ }^{158}$ La cuestión del sub examine — por la que se le endilgó responsabilidad internacional al Estado argentino en razón de los derechos de propiedad comunitaria, identidad cultural, a un medio ambiente sano, a la alimentación adecuada y al agua - versó sobre un reclamo emprendido por distintas comunidades («Mataco», «Chorote», «Toba», «Chulupí» y «Tapiete») por los lotes fiscales 14 y 55 (dentro de la Provincia de Salta que, a su vez, limita con los Estados de Paraguay y Bolivia) que han atestiguado, desde 1629, tanto la presencia de pueblos indígenas como, a partir de comienzos del siglo XXI, de personas criollas. Las peticiones por estas tierras datan del año 1991, las cuales llevaron a que, mediante el Decreto 2609/91, se estableciera la obligación de unificar dichos lotes. Con posterioridad, en 1992 se conformó la asociación Lhaka Honhat —integrada por miembros de diversas comunidades originarias- con el fin de obtener el título de propiedad de la tierra. Sin embargo, en 1995 se comenzó la construcción de un puente internacional —ocupado pacíficamente por pueblos indígenas-, siendo que, en dicha oportunidad, el gobernador de Salta de aquel entonces se comprometiera a otorgar, mediante decreto, la totalidad de los terrenos a las comunidades. A pesar de ello, el Estado, en 1999, adjudicó fracciones de uno de los lotes reclamados (55), acto que fue dejado sin efecto por el máximo tribunal provincial. Con el transcurso del tiempo, y luego de varios sucesos ( $v$. gr., referéndum del año 2005 en el cual los habitantes de la Provincia se manifestaban a favor de la devolución de sus territorios a las comunidades originarias), permanecieron los inconvenientes, dada la falta de determinación específica del territorio y la existencia de lotes que corresponden a comunidades indígenas y criollas, sumado a actividades ilegales de tala y al desarrollo de la ganadería e instalación de alambrados por parte de familias criollas.

159 Paralelamente, reiteró su postura en cuanto a las tres garantías que, con motivo de obras o actividades dentro del territorio indígena, deben ser respetadas para «preservar, proteger y garantizar la relación especial» que las comunidades indígenas tienen con sus territorios (apdo. 175). En primer lugar, se debe «asegurar la participación efectiva de los pueblos» ateniéndose a sus «costumbres y tradiciones» y las «consultas deben realizarse de buena fe, a través de procedimientos culturalmente adecuados»; en segundo lugar, la no ejecutoriedad de las obras hasta tanto no se «realice un estudio previo de impacto ambiental»y, finalmente, que las comunidades «se beneficien razonablemente del plan que se lleve a cabo dentro de su territorio» (apdo. 174). 
car un entendimiento irrazonable o excesivo de las obligaciones estatales correlativas a los derechos de consulta y participación» (cfr. apdo. 179). Por último, la Corte destacó —entre otros puntos cardinales— ${ }^{160}$ que la conservación de los recursos naturales ${ }^{161}$ por parte de las comunidades originarias coadyuva -más allá de los beneficios que apareja para sus miembros- a «la preservación del ambiente» (apdo. 250) ${ }^{162}$.

Finalmente, cabe mencionar que la Corte, con motivo de la interpretación de la sentencia en la causa mencionada con antelación (Lhaka Honhat), el 24 de noviembre de 2020 recordó que las medidas legislativas y/o de otro carácter que el Estado adopte para otorgar mayor seguridad jurídica al derecho de propiedad comunitaria deben ser establecidas en consonancia con el derecho a la consulta previa, adecuada, libre e informada —asegurando «la participación efectiva» de los pueblos- en tanto que lo contrario supondría la afectación al derecho de propiedad comunitaria (vid. apdo. 24) ${ }^{163}$.

\subsection{Breves menciones de su faz consultiva en torno a los pueblos indígenas}

Por último caber recordar que la Corte IDH ya se ha manifestado —en lo que hace a la cuestión indígena- por el cauce de su competencia consultiva que le confiere el art. $64 \mathrm{CADH}$ (cfr. art. 2.2 del Estatuto).

En lo tocante a esta función (consultiva), el Tribunal, a raíz de la solicitud ${ }^{164}$ que le dirigiera la República de Panamá, emitió el 26 de febrero de 2016 su dictamen en la Opinión Consultiva (OC) 22/16 ${ }^{165}$, por el cual

${ }^{160}$ Algunos se encuentran vinculados — como se pronunció en el caso Awas Tingni-a la «certeza geográfica» que el Estado debe otorgar a la propiedad comunitaria (apdo. 96) o también al deber del Estado de otorgar seguridad jurídica a la comunidad, sea por un título formal de propiedad $\mathrm{u}$ «otra forma similar de reconocimiento estatal» (apdo. 115).

${ }^{161}$ Los mismos constituyen, en conjunto con la tierra y el territorio, «una cuestión de derechos humanos esencial para la supervivencia de los pueblos indígenas» (apdo. 253).

162 Vid. https://www.corteidh.or.cr/docs/casos/articulos/seriec_400_esp.pdf (consultado el 7 de diciembre de 2020).

163 Vid. https://www.corteidh.or.cr/docs/casos/articulos/seriec_420_esp.pdf (consultado el 16 de diciembre de 2020).

${ }^{164}$ La presentación del 28 de abril de 2014 versó sobre el art. 1.2 vinculado con los arts. 1.1., 8, 11.2, 13, 16, 21, 24, 25, 29, 30, 44, 46 y $62.3 \mathrm{CADH}$, así como del art. 8.1.a) y b) del Protocolo de San Salvador.

165 Vid. bttps://www.corteidh.or.cr/docs/opiniones/seriea_22_esp.pdf (consultado el 7 de diciembre de 2020). 
concluiría — haciendo hincapié en el «contexto interno del tratado» ${ }^{166}$ y en el art. 1.2 CADH— que las personas jurídicas no son titulares de derechos convencionales, no siendo, por tanto, consideradas como presuntas víctimas en el marco de los procesos contenciosos ante el Sistema Interamericano de Derechos Humanos.

Ahora bien, y en lo que aquí interesa, la Corte, haciendo un repaso de los distintos estadios jurisprudenciales en los que se trató la cuestión indígena — siendo que en una primera etapa ${ }^{167}$ consideraba sujetos de derechos «a los miembros de las comunidades» mas no a estas últimas (apdo. 73) puso de relieve, con especial atención en el precedente del año 2012 Kichwa de Sarayaku y a disposiciones normativas supranacionales (Convenio 169 de la OIT y UNDRIP), que las «comunidades indígenas y tribales son titulares de algunos de los derechos protegidos en la Convención» (apdo. 84), en tanto que, en el marco del derecho a la «libre determinación» (apdo. 79), hay derechos «cuyo ejercicio se hace de forma colectiva» (apdo. 74), es decir, que conllevan, como en el caso del «derecho a la propiedad o a su territorio» (apdo. 83), una «dimensión colectiva» (apdo. 75) ${ }^{168}$.

Más tarde, en la OC 23/17 ${ }^{169}$, el Estado de Colombia le solicitó a la Corte que delineara las obligaciones de los Estados en relación con el medio ambiente en el marco de la protección y garantía de los derechos a la vida y a la integridad personal. En lo medular, la Corte advirtió la interrelación existente entre «medio ambiente y derechos humanos», aún más para aquellos supuestos en los que se encuentren en juego los derechos territoriales de los pueblos indígenas y tribales, en vista de que - de conformidad con el art. $19^{170}$ de la Declaración Americana sobre los Derechos

166 Esto es, tanto en el preámbulo de la CADH como en las primeras consideraciones de la Declaración Americana de Derechos y Deberes del Hombre, en cuanto plasman que fueron creadas con la intención de centrar la protección y la titularidad de los derechos en el ser humano. Para arribar a tal determinación, la Corte IDH hizo uso de los métodos interpretativos estipulados en la Convención de Viena sobre el Derecho de los Tratados («sentido corriente del término», «buena fe», «objeto» $\mathrm{y}$ «fin» del mismo, «contexto interno del tratado» y la «interpretación evolutiva»).

${ }_{167}$ Al respecto, el Tribunal alude, entre sus antecedentes, a los casos Comunidad Mayagna, Comunidad Yakye Axa y Pueblo Saramaka, entre otros (vid. nota 119 de la aquí referida OC).

${ }_{168}$ Vid. https://www.corteidh.or.cr/docs/opiniones/seriea_22_esp.pdf (consultado el 7 de diciembre de 2020).

169 La misma se emitió con posterioridad a la celebración de la Declaración Americana sobre los Derechos de los Pueblos Indígenas (15 de junio de 2016).

${ }^{170} \mathrm{El}$ mismo dispone el derecho que tienen las comunidades originarias a un ambiente sano y, con ello, al disfrute de otros derechos fundamentales ( $v$. gr., a la vida, a su espiritualidad, su cosmovisión y al bienestar colectivo). 
de los Pueblos Indígenas- esta clase de derechos (propiedad comunal) ${ }^{171}$ están inescindiblemente vinculados con «la protección y acceso a los recursos». Ello puesto que, considerando la especial protección —como «grupos especialmente vulnerables a los daños ambientales» (apdo. 67) que merecen estas comunidades, resultan necesarios para «la propia supervivencia, desarrollo y continuidad del estilo de vida de dichos pueblos» (apdo. 48). Sin embargo, el Tribunal también señaló que tal panorama en el marco de la $\mathrm{CADH}$ - no puede ser entendido como la imposibilidad de los Estados de otorgar concesiones para la exploración o explotación de recursos naturales, siempre reparando en los estudios de impacto ambiental que, para el caso de pueblos indígenas ${ }^{172}$, deben coadyuvar abarcando el «impacto social que implique el proyecto» (apdo. 164) - a «su propia supervivencia» (apdo. 138) ${ }^{173}$. Sobre esa base, e invocando el precedente Kaliña Lokono, sopesó la correlación que guardan los deberes de «supervisar y fiscalizar» con la protección de las áreas naturales de las comunidades indígenas (apdo. 152). Se sigue de ello el control democrático que ejerza la sociedad mediante el acceso a la información que, tal como acontece con las actividades de exploración y explotación de recursos en territorios indígenas, resulta de interés público (apdo. 214) ${ }^{174}$.

Ese mismo año, la Corte se vio llamada a manifestarse en la cuestión de «género», dada la petición que le cursara el Estado de Costa Rica el 18 de mayo de 2016. De esta manera, en su OC 24/17 («Identidad de género e igualdad y no discriminación a parejas del mismo sexo») elaboró un concepto de discriminación precisando, con base en instrumentos locales ${ }^{175}$

${ }^{171}$ Al respecto, el Tribunal consideró que este derecho colectivo perteneciente a los pueblos indígenas y tribales es indispensable para que disfruten de otros derechos - también colectivos-, tales como «su identidad cultural» (apdo. 113).

${ }^{172}$ Los cuales deben participar, mediante la consulta — disímil a la consulta interestatal (apdo. 197)—, de todas aquellas etapas que impliquen el mentado estudio (apdo. 166); derecho este extensible a todas «las fases de planeación e implementación de un proyecto o medida que pueda afectar» a sus territorios u otros derechos de análoga connotación para su supervivencia (deber de conocimiento de los posibles riesgos ambientales y de salubridad) (apdo. 227).

${ }^{173} \mathrm{Y}$ es que el estudio de impacto ambiental — cuyos resultados de aceptabilidad diferirán en cada caso concreto- constituye la «salvaguarda» para la subsistencia de los pueblos indígenas y tribales (apdo. 156), debiendo, a través del mismo — con primordial atención en la conexión intrínseca de los miembros de las comunidades con sus territorios-, respetar sus tradiciones y culturas (apdo. 169).

${ }_{174}$ Vid. https://www.corteidh.or.cr/docs/opiniones/seriea_23_esp.pdf (consultado el 8 de diciembre de 2020).

${ }_{175}$ Tales como la Convención Interamericana sobre la Protección de los Derechos Humanos de las Personas Mayores; la Convención Interamericana para la Eliminación de 
y en los trabajos del Comité de Derechos Humanos de la ONU, que la misma apareja «toda distinción, exclusión, restricción o preferencia que se basen en determinados motivos, como la raza, el color, el sexo, el idioma, la religión, la opinión política o de otra índole, el origen nacional o social, la propiedad, el nacimiento o cualquier otra condición social, y que tengan por objeto o por resultado anular o menoscabar el reconocimiento, goce o ejercicio, en condiciones de igualdad, de los derechos humanos y libertades fundamentales de todas las personas» (apdo. 62), existiendo, en esa línea, «un vínculo indisoluble entre la obligación de respetar y garantizar los derechos humanos y el principio de igualdad y no discriminación» (apdo. 63 in fine). Asimismo, caviló —entre sus ponderaciones más relevantesla obligación que recae sobre los Estados de adoptar medidas positivas ${ }^{176}$ para revertir o cambiar situaciones discriminatorias existentes en sus sociedades en perjuicio de determinado grupo de personas (apdo. 65). De tal suerte, y con basamento particular en la UNDRIP, en cuanto contempla una acepción amplia de «sistemas de familias» — propios de los pueblos indígenas (cfr. apdo. 185)—, determinó que debía ceñirse a una interpretación evolutiva en lo que implica la constitución de las familias, por lo que no hay óbice alguno para que exista un «vínculo familiar» proveniente de la relación de una pareja del mismo sexo (apdo. 199) ${ }^{177}$.

todas las Formas de Discriminación contra las Personas con Discapacidad; la Convención Interamericana contra toda Forma de Discriminación e Intolerancia; la Convención Interamericana contra el Racismo, la Discriminación Racial y Formas Conexas de Intolerancia; la Convención Internacional sobre la Eliminación de todas las Formas de Discriminación contra la Mujer, y la Convención Internacional sobre la Eliminación de todas las Formas de Discriminación Racial. Consideramos de vital importancia estos «acontecimientos jurídicos» (el auxilio en otros instrumentos) en vista de que son los mismos los que plasman la progresividad de los derechos fundamentales en el sistema tutelar en la materia, ya que - para el caso- si bien los redactores de la Convención Americana de 1969 no habían previsto ciertas cuestiones (género, pueblos originarios, etc.), ello no obsta, con basamento en otros tratados, a su protección convencional. Se recurrió a estas disposiciones normativas debido a la falta de un concepto de discriminación en el Pacto de San José.

${ }^{176}$ Es lo que se conoce como acción afirmativa o «discriminación positiva» (contemplada en el párrafo cuarto del Preámbulo de la Convención Interamericana contra el Racismo: «adoptar medidas especiales en favor de los derechos de los individuos o grupos que son víctimas de discriminación racial», y expresamente en los arts. 1.5 y 5 del mismo decálogo, los cuales establecen que no constituye discriminación «las medidas especiales o acciones afirmativas», a los fines de garantizar condiciones de «igualdad»). Vid. http://www.oas.org/es/ sla/ddi/docs/tratados_multilaterales_interamericanos_A-68_racismo.pdf (consultado el 25 de octubre de 2020).

177 Vid. https://www.corteidh.or.cr/docs/opiniones/seriea_24_esp.pdf (consultado el 7 de diciembre de 2020). 


\section{PALABRAS FINALES}

De lo hasta aquí comentado se infiere lo medular del horizonte colectivo que afecta a los pueblos indígenas donde, con la «propiedad comunal», se expone la amplia gama de derechos que se encuentran en juego, dando cuenta, en consecuencia, de la interrelación e interdependencia que guardan esta clase de derechos (identidad cultural, consulta, consentimiento libre, previo e informado, etc.).

Por lo demás, resulta cardinal comprender que, en nombre de la alteridad, este panorama (colectivo-diferencial) no puede ser interpretado en el sentido — contraproducente- de que a estas comunidades se las sitúe aún más aisladamente en la sociedad. En otras palabras, en razón de sus diferencias como colectivo, no se puede concebir a las mismas como un conjunto de islas separadas, sino que deben coadyuvar a que se las entienda como una península.

Así, tampoco se deben soslayar —en ningún supuesto- los derechos individuales que atañen a cada uno de sus miembros. En ese entendimiento cabe recordar el reciente caso — entre tantos otros- de la niña perteneciente a la comunidad Wichi (Provincia de Salta) quien falleciera, a raíz de la ausencia estatal en la atención nutricional y sanitaria ${ }^{178}$, con casi solo dos años de edad.

Por tal motivo es menester señalar que esta dimensión colectiva de los pueblos no debe prescindir de los derechos individuales, pues ¿en qué medida podrían disfrutar su derecho a tierras, territorios y recursos, cuando sus miembros no cuentan con servicios básicos en distancias prudenciales $\mathrm{o}$, ante cualquier emergencia, con medios radiales?

Y es que, de lo contrario, estas comunidades serían «sentenciadas» culturalmente (léase estigmatizadas), desconociendo, de esa forma, su carácter «histórico, dinámico y evolutivo» ${ }^{179}$.

Finalmente, sobre la base de lo expuesto, quisiera concluir estas meras reflexiones citando un pasaje del libro del jurista y etnógrafo rosarino Estanislao Zeballos, quien en su obra de 1878 La conquista de quince mil lenguas relata: «Los indios que vagan en los llanos de la Patagonia al sur del Río Negro no son invasores, porque su índole y sus costumbres difie-

$178 \mathrm{Vid}$. https://nuevodiariodesalta.com.ar/noticias/salta-1/muere-una-ninia-wichi-primera-victima-de-la-temporada-estival-50736 (consultado el 16 de diciembre de 2020).

179 Apartado 240 in fine de la causa Comunidades indígenas Miembros de la Asociación Lhaka Honhat vs. Argentina (Sentencia de 6 de febrero de 2020). 
ren radicalmente de los caracteres morales y elementos materiales de los araucanos. Los Tehuelches o habitantes del sur (Tehuel, sur; ché, gente) son indios naturalmente preparados para la civilización y "algún día serán la base de la población argentina de la Patagonia" ${ }^{180}$ (las comillas me pertenecen).

\section{BIBLIOGRAFÍA}

Alarcón G.; Díaz, J.; Vela, M.; García, M., y Gutiérrez, J.: «Deforestación en el sureste de la Amazonia del Perú entre los años 1999-2003: caso Región de Madre de Dios (Puerto Maldonado-Inambari)», Revista de Investigaciones Altoandinas, núm. 3 (2016), pp. 319-330.

BARABAS, A.: «La construcción del indio como bárbaro: de la etnografía al indigenismo», Alteridades, núm. 10 (2000), pp. 9-20.

- «Cosmovisiones y etnoterritorialidad en las culturas indígenas de Oaxaca», Antípoda: Revista de Antropología y Arqueología, núm. 7 (2008), pp. 119-139.

Benedetti, M. A., y SÁenz, M. J.: «Decisión judicial y participación ciudadana: los impactos de las audiencias públicas en las sentencias de la Corte Suprema argentina», Eunemia, núm. 15 (2018-2019), pp. 102-122.

CARmen, A.: «Informe desde el campo de batalla del Consejo Internacional de Tratados Indios: la lucha por la Declaración», en C. CHARTERS y R. STAVENHAGEN (eds.), El desafío de la declaración. Historia y futuro de la declaración de la ONU sobre pueblos indígenas, Copenhague, IWGIA, 2010, pp. 90-101.

Chartes, C.: «La legitimidad de la Declaración de la ONU sobre los Derechos de los Pueblos Indígenas», en C. Charters y R. Stavenhagen (eds.), El desafío de la declaración. Historia y futuro de la declaración de la ONU sobre pueblos indígenas, Copenhague, IWGIA, 2010, pp. 301-320.

Clastres, P.: «Sobre el etnocidio», en Investigaciones en antropología política, Barcelona, Gedisa, 1996, pp. 55-64.

Clavero, B.: «Pronunciamientos indígenas de las Constituciones americanas», 2013, disponible en $\mathrm{bttp} / / / w w w$ alertanet.org/constitucion-indigenas.htm (consultado el 9 de diciembre de 2020).

- «La Declaración Americana sobre Derechos de los Pueblos Indígenas: el reto de la interpretación de una norma contradictoria», lección impartida en el acto de recepción de la condecoración José León Barandarián de la Facultad de

${ }^{180}$ E. Zeballos, La conquista de quince mil leguas. Estudio sobre la traslación de la frontera sud de la República al Río Negro. Dedicado á los gefes y oficiales del ejército expedicionario, 2. ${ }^{a}$ ed., Buenos Aires, Establecimiento Tipográfico a vapor de La prensa, 1878, pp. 287-288, disponible en https://ia800304.us.archive.org/2/items/laconquistadequi00zebal laconquistadequi00zeba_bw.pdf (consultado el 10 de diciembre de 2020). 
Derecho y Ciencias Políticas de la Universidad Nacional mayor de San Marcos, Perú, 2016, pp. 1-12.

Colmenares Olivar, R.: «El derecho a la autonomía de los pueblos indígenas en Venezuela», Revista del Centro de Investigaciones Penales Criminológicas Héctor Febres Cordero (CENIPEC), núm. 21 (2002), pp. 185-217.

Del Cairo, C., y Jaramillo Marín, J.: «Clifford Geertz y el ensamble de un proyecto antropológico crítico», Tabula Rasa: Revista de Humanidades núm. 8 (2008), pp. 15-41, disponible en https://revistas.unicolmayor.edu.co/index.php/ tabularasa/article/view/1509/2042 (consultado el 24 de noviembre de 2020).

Domenech, E.: «El Banco Mundial en el país de la desigualdad: políticas y discursos neoliberales sobre diversidad cultural y educación en América Latina», en Cultura y Neoliberalismo, Buenos Aires, CLACSO, 2007, pp. 61-89.

FAJARDO, R. Y.: «De la tutela indígena a la libre determinación del desarrollo, la participación, la consulta y el consentimiento», en L. G. UsCÁtegui GómEZ (ed.), El derecho a la consulta previa en América Latina. Del reconocimiento formal a la exigibilidad de los derechos de los pueblos indígenas, Bogotá, Instituto Latinoamericano de Servicios Legales Alternativo, 2009, pp. 11-48.

- «El horizonte del constitucionalismo pluralista: del multiculturalismo a la descolonización», en C. Rodríguez Garavito (coord.), El Derecho en América Latina. Un mapa para el pensamiento jurídico del siglo XXI, Buenos Aires, Siglo XXI, 2011, pp. 138-159.

García Acosta, V.; De Oliveria, L. A. C.; Ramos, A. R., y Oliva, M.: «Diálogos México-Brasil», Desacatos: Revista de Ciencias Sociales, núm. 39 (2012), pp. 161-184.

Gomiz, M. M., y Salgado, J. M.: Convenio 169 de la OIT sobre pueblos indígenas. Su aplicación en el Derecho interno argentino, 2. ${ }^{a}$ ed., Neuquén (Argentina), Observatorio de Derechos Humanos de los Pueblos Indígenas, 2010.

Gordillo, G., y Hirsch, S.: Movilizaciones indígenas e identidad en disputa en la Argentina, Programa en Antropología Social y Política de FLACSO, Buenos Aires, La Crujía, 2010, pp. 15-38.

Grau, A. E.: Habilitación de la instancia contencioso-administrativa, La Plata, Editora Platense, 1971, p. 1198.

ITURRALDE, D.: «Demandas indígenas y reforma legal: retos y paradojas», Alteridades, núm. 14 (1997), pp. 81-98.

Kymlicka, W.: Ciudadanía multicultural: una teoría liberal de los derechos de las minorías, Barcelona, Paidós Ibérica, 1996.

LlancaqueO, V.: «Políticas indígenas y derechos territoriales en América Latina, 1900-2004. ¿Las fronteras indígenas de la globalización?» en P. DÁvALos (coord.), Pueblos indígenas, estado y democracia, Buenos Aires, CLACSO, 2005, pp. 67-102.

Ordóñez Cifuentes, J. E. R.: Cuadernos constitucionales México-Centroamérica 30. La opinión consultiva de la Corte de Guatemala sobre la constitucionalidad del 
Convenio 169. Una experiencia constructiva en favor de la paz, República de Guatemala, Centro de Estudios Constitucionales México-Centroamérica-Instituto de Investigaciones Jurídicas-Universidad Nacional Autónoma de México-Corte de Constitucionalidad, 1998 (capítulo VIII, «Otras disposiciones de la OIT vinculadas a los derechos de los pueblos indígenas»).

Post, R. C.: «Constitucionalismo democrático y heterogeneidad cultural», Revista Jurídica, núm. 1 (2008), pp. 5-26 (el artículo fue publicado originalmente en el año 2000 en Australian Journal of Legal Philosophy, vol. 25, núm. 2).

Regino Montes, A., y Torres Cisneros, G.: «La Declaración de las Naciones Unidas sobre los derechos de los pueblos indígenas: base de la nueva relación entre los pueblos indígenas, los Estados y las sociedades», en C. CHARTERs y R. STAvENHAGEN (eds.), El desafío de la declaración. Historia y futuro de la declaración de la ONU sobre pueblos indígenas, Copenhague, IWGIA, 2010, pp. 146-177.

Rodríguez-Piñero Royo, L.: «"Cuando proceda": vigilancia y aplicación de los derechos de los pueblos indígenas según la declaración», en C. CHARTERS y R. Stavenhagen (eds.), El desafío de la declaración. Historia y futuro de la declaración de la ONU sobre pueblos indígenas, Copenhague, IWGIA, 2010, pp. 336-365.

Shakespeare, W.: La Tempestad, traducida al castellano por M. Palazón Blasco, Madrid, Bubok, 2011.

Unda, R. L., y SolóRZAno, M. F.: «Jóvenes indígenas en la Sierre Central de Ecuador. Elementos para pensar sus prácticas comunitarias», Desidades: Revista Electrónica de Divulgación Cientifica de la Infancia y la Juventud, vol. 2, núm. 4 (2014), pp. 9-19.

VAsallo, F. J.: «El estoppel: dificultades para definir una regla en Derecho internacional y el rol deslucido de la Corte Internacional de Justicia», Lecciones y Ensayos, núm. 91 (2013), pp. 181-191.

Williensen-Díaz, A.: «Cómo llegaron los derechos de los pueblos indígenas a la ONU», en C. Charters y R. Stavenhagen (eds.), El desafío de la declaración. Historia y futuro de la declaración de la ONU sobre pueblos indígenas, Copenhague, IWGIA, 2010, pp. 16-33.

YAÑEZ, N.: «OEA: Declaración vulnera derechos de los pueblos indígenas», 2016, disponible en bttps://www.servindi.org/actualidad-opinion/23/06/2016/observan-limitaciones-en-declaracion-americana-sobre-derechos-de-los (consultado el 18 de diciembre de 2020).

Zeballos, E. S.: La conquista de quince mil leguas. Estudio sobre la traslación de la frontera sud de la República al Río Negro. Dedicado á los gefes y oficiales del ejército expedicionario, 2. ${ }^{a}$ ed., Buenos Aires, Establecimiento tipográfico a vapor de La prensa, 1878. 


\section{APÉNDICE JURISPRUDENCIAL}

Caso de la Comunidad Mayagna (Sumo) Awas Tingni c. Nicaragua, Fondo, Reparaciones y Costas, Sentencia de 31 de agosto de 2001, Serie C, núm. 79.

Caso de la Comunidad Moiwana c. Surinam, Excepciones Preliminares, Fondo, Reparaciones y Costas, Sentencia de 15 de junio de 2005, Serie C, núm. 124.

Caso Comunidad Indígena Yakye Axa c. Paraguay, Fondo, Reparaciones y Costas, Sentencia de 17 de junio de 2005, Serie C, núm. 125.

Caso Yatama c. Nicaragua, Excepciones Preliminares, Fondo, Reparaciones y Costas, Sentencia de 23 de junio de 2005, Serie C, núm. 127.

Caso Comunidad Indigena Sawhoyamaxa c. Paraguay, Fondo, Reparaciones y Costas, Sentencia de 29 de marzo de 2006, Serie C, núm. 146.

Caso del Pueblo Saramaka c. Surinam, Excepciones Preliminares, Fondo, Reparaciones y Costas, Sentencia de 28 de noviembre de 2007, Serie C, núm. 172.

Caso del Pueblo Saramaka c. Surinam, Interpretación de la Sentencia de Excepciones Preliminares, Fondo, Reparaciones y Costas, Sentencia de 12 de agosto de 2008, Serie C, núm. 185.

Caso Comunidad Indígena Xákmok Kásek. c. Paraguay, Fondo, Reparaciones y Costas, Sentencia de 24 de agosto de 2010, Serie C, núm. 214.

Caso Pueblo Indígena Kichwa de Sarayaku c. Ecuador, Fondo y Reparaciones, Sentencia de 27 de junio de 2012, Serie C, núm. 245.

Caso de los Pueblos Indígenas Kuna de Madungandí y Emberá de Bayano y sus miembros c. Panamá, Excepciones Preliminares, Fondo, Reparaciones y Costas, Sentencia de 14 de octubre de 2014, Serie C, núm. 284.

Caso Comunidad Garifuna de Punta Piedra y sus miembros c. Honduras, Excepciones Preliminares, Fondo, Reparaciones y Costas, Sentencia de 8 de octubre de 2015, Serie C, núm. 304.

Caso Comunidad Garifuna Triunfo de la Cruz y sus miembros c. Honduras, Fondo, Reparaciones y Costas, Sentencia de 8 de octubre de 2015, Serie C, núm. 305.

Caso Pueblos Kaliña y Lokono c. Surinam, Fondo, Reparaciones y Costas, Sentencia de 25 de noviembre de 2015, Serie C, núm. 309.

Caso Pueblo Indígena Xucuru y sus miembros c. Brasil, Excepciones Preliminares, Fondo, Reparaciones y Costas, Sentencia de 5 de febrero de 2018, Serie C, núm. 346.

Caso Comunidades Indígenas Miembros de la Asociación Lbaka Honbat (Nuestra Tierra) c. Argentina, Fondo, Reparaciones y Costas, Sentencia de 6 de febrero de 2020, Serie C, núm. 400.

Caso Comunidades Indígenas Miembros de la Asociación Lhaka Honbat (Nuestra Tierra) c. Argentina, Interpretación de la Sentencia de Fondo, Reparaciones y Costas, Sentencia de 24 de noviembre de 2020, Serie C, núm. 420. 